Board of Governors of the Federal Reserve System

International Finance Discussion Papers

Number 889

January 2007

\title{
Markov Switching GARCH Models of Currency Turmoil in Southeast Asia
}

\author{
Celso Brunetti \\ Roberto S. Mariano \\ Chiara Scotti \\ Augustine H.H. Tan
}

NOTE: International Finance Discussion Papers are preliminary materials circulated to stimulate discussion and critical comment. References in publications to International Finance Discussion Papers (other than an acknowledgment that the writer has had access to unpublished material) should be cleared with the author or authors. Recent IFDPs are available on the Web at www.federalreserve.gov/pubs/ifdp/. This paper can be downloaded without charge from Social Science Research Network electronic library at http://www.ssrn.com/. 


\title{
MARKOV SWITCHING GARCH MODELS OF CURRENCY TURMOIL IN SOUTHEAST ASIA
}

\author{
Celso Brunetti \\ Johns Hopkins University \\ Chiara Scotti \\ Federal Reserve Board
}

\author{
Roberto S. Mariano \\ Singapore Management University \\ Augustine H.H. Tan \\ Singapore Management University
}

January $2007 *$

\begin{abstract}
This paper analyzes exchange rate turmoil with a Markov Switching GARCH model. We distinguish between two different regimes in both the conditional mean and the conditional variance: "ordinary" regime, characterized by low exchange rate changes and low volatility, and "turbulent" regime, characterized by high exchange rate movements and high volatility. We also allow the transition probabilities to vary over time as functions of economic and financial indicators. We find that real effective exchange rates, money supply relative to reserves, stock index returns, and bank stock index returns and volatility contain valuable information for identifying turbulence and ordinary periods.
\end{abstract}

Keywords: Currency crises; Financial markets; Banking sector; Regime switching; Volatility.

JEL classification: C13; C22; C52; F31; F34.

\footnotetext{
${ }^{*}$ We would like to thank for helpful comments: Mark Carey, Graciela Kaminsky, Adrian Pagan, Jon Wongswan, and participants at the EC2 conference in Bologna 2002 and ASSA meeting in Washington DC 2003. The authors gratefully acknowledge funding support from the Wharton Singapore Management University Research Center. The views expressed in this paper are solely the responsibility of the authors and should not be interpreted as reflecting the view of the Board of Governors of the Federal Reserve System or of any other person associated with the Federal Reserve System.
} 


\section{Introduction}

The decade of the nineties witnessed several bank and currency crises. ${ }^{1}$ The severity of the crises has motivated researchers to develop early warning systems in order to forestall similar crises. Such early warning systems typically involve some precise definition of a crisis and a mechanism for predicting it. A currency crisis is usually identified as an episode in which there is a sharp depreciation of the currency, a large decline in foreign reserves, a dramatic increase in domestic interest rates or a combination of these elements.

This paper studies exchange rate turmoil, that is, we focus on episodes of extensive exchange rate changes, and we analyze which variables trigger the move from a tranquil period to a turbulent time. Since a currency crisis is not necessarily a turbulent period, and vice versa, our approach identifies currency crises only when they manifest with large exchange rate devaluations. Our modeling strategy relies on the empirical evidence that i) small exchange rate changes are associated with low volatility (ordinary regime) and large exchange rate movements go together with high volatility (turbulence), and ii) exchange rate volatility is not constant in the two regimes. This calls for a GARCH regime switching approach, in which we furthermore allow the transition probabilities to vary over time as functions of economic and financial indicators. Switching volatility models have been used for modeling equity markets (Hamilton and Susmel, 1994; Dueker, 1997; Susmel, 2000), short-term interest rates (Cai, 1994; Gray, 1996; Kalimipalli and Susmel, 2006), emerging equity markets (Susmel, 1998), and exchange rates (Klaassen, 2002; Calvet and Fisher, 2004). However, to the best of our knowledge, this paper is the first application to currency turmoil.

The analysis is applied to four Southeast Asian countries: Thailand, Singapore, the Philippines, and Malaysia. Estimation results support our intuition for modeling exchange rate volatilities. Our results, in fact, show that signals of the July 1997 crisis become apparent in Thailand as early as January, and the probability of getting into a crisis jumps to as much as 82 percent in June 1997.

The literature on financial/currency crises is vast, and it mainly focuses on trying to predict crises in developing countries. There are three methods or approaches for predicting currency crises that have been developed in the literature.

One class of models is the probit regression approach of Frankel and Rose (1996). They use probit analysis on a panel of annual data for 105 developing countries from 1971-92. The hypothesis tested is that currency crashes are positively linked to certain characteristics of capital inflows, such as low shares of foreign direct investments (FDI); low shares of concessional debt or debt from multilateral development banks; and high shares of public-sector, variable short-term,

\footnotetext{
${ }^{1}$ Europe in 1992-93 (the European Exchange Rate mechanism); Mexico in 1994-95; Turkey in 1994 and 2000-01; East and Southeast Asia in 1997; Russia in 1998; and Argentina, Uruguay and Brazil starting in late 2001.
} 
and commercial bank debt. The finding is that currency crises are more likely when foreign interest rates are high, domestic credit growth is high, the real exchange rate is overvalued, the current account deficit and fiscal deficit are large (as a share of GDP), external concessional debt is small, and FDI is small in relation to the total volume of external debt. However, when the model is used to generate out-of-sample predictions for the 1997 Asian Crisis, the forecasts are not successful (Berg and Patillo, 1999a). ${ }^{2}$ More recently Bussiere and Fratzcher (2006) develop a new early warning system model based on a multinomial logit with three outcomes (tranquil, precrisis and post-crisis) showing that such a specification leads to a better out-of-sample forecast and solves what they call the "post-crisis bias."

A second class of models (Tornell, 1999; IMF, World Economic Outlook, 1998; Radelet and Sachs, 1998; Corsetti Pesenti and Roubini,1999) follows Sachs, Tornell and Velasco (1996) who use cross-country regressions to explain the Tequila (Mexican) crisis of 1995. Using a crisis index defined as the weighted sum of the percentage decrease in foreign reserves and the percentage depreciation of the peso, they conclude that countries have more severe attacks when they have low foreign reserves, their banking systems are weak and their currencies overvalued. Berg and Patillo (1999a) extend the data to 23 other countries and conclude that the Sachs, Tornell and Velasco (1996) model proved to be largely unstable. Specification uncertainty appeared to be as important as parameter uncertainty.

The third class of models, attributed to Kaminsky, Lizondo and Reinhart (1998), is the "signals approach." A crisis is defined as a situation in which a weighted average of monthly percentage depreciations in the currency and monthly percentage declines in reserves exceeds its mean by more than three standard deviations. They use 15 monthly variables to monitor for unusual behavior during a 24-month window prior to a crisis. Threshold levels, beyond which signals would be generated, are specified. Using variants of the signals approach, Kaminsky (1998a and 1998b), Kaminsky and Reinhart (1999), and Goldstein, Kaminsky and Reinhart (2000) claim some success in predicting the Asian crisis.

These approaches have some limitations. For example, the signal approach requires the ex-ante definition of a threshold and the transformation of the variables into binary variables, with a significant loss of information; the logit/probit approach requires the definition of a crisis dummy, with potential misclassifications.

We use a Markov switching approach in which we account for the presence of two potential regimes: ordinary and turbulent. We also recognize the fact that, even within each regime, the volatility of exchange rate returns is not constant, and we therefore include a GARCH

\footnotetext{
${ }^{2}$ See also Berg and Patillo (1999b). A more recent paper by Kumar, Moorthy and Perraudin, 2003, applied logit models to pooled data on 32 developing countries for the period January 1985 to October 1999. The results confirm those of earlier studies that factors such as declining reserves, exports and declining real activity are the most important explanatory variables for currency crashes.
} 
specification. The probabilities of switching between the two regimes are time-varying. The attractiveness of this approach is that we do not need to distinguish ex-ante between ordinary and turbulent times, but we let the estimation results supply us with this information. We differ from Mariano et al. (2002) in that we recognize the importance of volatility dynamics, and we enlarge the set of potential explanatory variables to include the M2-reserve ratio, real domestic credit, real effective exchange rate, stock market returns and volatility, and banking sector returns and volatility.

The model can be used for out-of-sample forecasting. Unfortunately, the short sample does not allow us to do so in the current paper (GARCH models require long datasets). Therefore, we only limit our study to understanding the variables and modeling specifications which play a role in comprehending currency turmoil, leaving the out-of-sample forecast exercise to future assessment.

This paper proceeds in Section 2 by motivating the use of a Markov switching GARCH model. Section 3 presents the model. Section 4 illustrates the data used in the estimation. Section 5 presents the estimation results toghether with an analysis of the estimated timevarying transition probabilities. Section 6 concludes the paper.

\section{Motivating our Approach}

The goal of the paper is to study episodes of high (low) risk and high (low) exchange rate movements.

Our approach consists in modeling the conditional mean and the conditional variance of the exchange rate devaluation. The first and the second order moments of exchange rate devaluation are driven by the same Markov process governed by an unobservable state variable. The underlying assumption is quite simple: low mean values of exchange rate devaluation are associated with low volatility of the exchange rate devaluation, and high devaluation is associated with high volatility. We refer to the latter regime as "turbulence" and the former as describing "ordinary" market conditions. In addition, the transition probabilities in the Markov process are functions of macroeconomic and/or financial variables. This captures the idea that large exchange rate devaluations and high risk might be driven by exogenous variables.

This approach might lead to identify currency crises. In fact, there is empirical evidence (see below) showing that, at least for the four Southeast Asian countries analyzed in this paper, high risk and high exchange rate devaluation correspond indeed to the 1997 currency crises.

The countries considered are Thailand, Singapore, Malaysia and Philippines. The sample period runs from November 1984 to December 2001.

A difference of our approach from the previous literature is the emphasis on the volatility process of exchange rate movements. To motivate our accent on the volatility of exchange rate 
returns, we compute a volatility proxy: the range, ${ }^{3}$ which is defined as the difference between the maximum value of the (log of the) price process over a given interval of time and the minimum value of the (log of the) price process over the same interval

$$
l=\max _{0 \leq n \leq N}\left[\ln \left(P_{n}\right)\right]-\min _{0 \leq n \leq N}\left[\ln \left(P_{n}\right)\right]
$$

Our data set is composed of monthly observations. The use of monthly data is due to the fact that many macroeconomic data used as explanatory variables for the time varying Markov probabilities, are available only at monthly frequencies. However, nominal exchange rate data is also available at daily frequencies. For each month and for each exchange rate analyzed we selected the highest (log) price and the lowest $(\log )$ price to compute the monthly range (see Chou, 2005). Therefore, the time interval $0 \leq n \leq N$ in our set up corresponds to a month. Finally, the volatility (standard deviation) proxy is computed as

$$
\widehat{\sigma}_{i, t}=\sqrt{\frac{\pi}{8}} l
$$

where $i$ indicates the four different exchange rates analyzed in the paper and $t$ refers to the monthly observation.

Figure 1 graphs the volatility proxy for the Thai baht. Figures for the other three countries look very similar.

\subsection{Time-Varying Volatilities Approach}

Since Mandelbrot (1963a, 1963b) and Fama (1965) it has been a well know fact that asset return volatility is not constant over time. Moreover, there is a large empirical evidence (among others see Brunetti and Lildholdt, 2002b) showing volatility clustering: large (small) changes in the nominal exchange rate tend to be followed by large (small) changes of either sign. These features are confirmed by our data. Figure 1 shows that volatility changes over time and evolves in clusters.

The GARCH model is able to capture both time varying volatility and volatility clustering. Baillie and Bollerslev (1989) shows that the GARCH class of models is able to capture the volatility dynamics of exchange rates at daily, weekly and monthly frequencies. Even if the GARCH effect dissipates as the length of the sampling interval increases, there is still heteroskedasticity and volatility clustering at monthly frequencies. $\operatorname{GARCH}(1,1)$ models have proved to adequately

\footnotetext{
${ }^{3}$ The volatility process is not directly observable. Many volatility proxies have been proposed in the literature. Most of them are functions of the return process (squared returns, absolute returns). We adopt a non-standard proxy: the range. Drawing on the results of Feller (1951), Parkinson (1980) shows that the range (properly rescaled) is an unbiased estimator of the volatility process. Moreover, Brunetti and Lildholdt (2002a) demonstrate that the range is superior to volatility proxies based on returns.
} 
describe exchange rate volatility dynamics. ${ }^{4}$ This is the approach we follow in this paper.

\subsection{Markov Regime Switching Approach}

As already stated, we model jointly the conditional mean and the conditional variance (volatility) of exchange rate devaluations. The Markov switching regime model adopted relies on two assumptions: i) the volatility process is characterized by two regimes, high volatility and low volatility; ii) the high volatility regime is associated with large exchange rate deviations (high values of the mean process) and the low volatility regime is associated with small exchange rate movements (low values of the mean process). The first assumption is confirmed by Figure 1. For all of the four countries analyzed, the volatility process exhibits periods of very low volatility and periods of very high volatility. Interestingly, the highest volatilities coincide with the 1997 crisis which is the major currency crisis that took place during our sample. Therefore this crisis represents our benchmark.

The onset of the crisis in Thailand, the first country to be hit by the crisis, was on July 1997. The average monthly volatility (standard deviation) in the 12 months after the crisis (July 1997 - June 1998) was more than seven times bigger than in the previous 12 months (July 1996 - June 1997). Similar results also apply to Singapore and Malaysia. For the Philippines the volatility in the twelve months subsequent the beginning of the crisis increased by a factor of 55 .

The second assumption simply implies that the same Markov process drives both the mean and the variance of exchange rate returns. Figure 2 displays the scatter plot of exchange rate devaluation and the volatility proxy for Thailand. It is evident that periods of zero or low exchange rate devaluation/appreciation are associated with low risk and periods of severe devaluations are associated with very high exchange rate risk. In the twelve months after the onset of the 1997 crisis the level of the exchange rate devaluation increased by a factor of 8 compared to the 12 months before. Similar results apply to the other three countries. The exchange rate devaluation increased by a factor of 12, 59 and 54 in Singapore, the Philippines and Malaysia respectively, when comparing the twelve months before and after the crisis.

It is interesting to note the asymmetry of exchange rate devaluation and volatility: in periods of high risk the currency devaluates. The largest outliers in Figure 2 refer to the 1997 crisis.

The presence of two regimes - low devaluation and low volatility versus high devaluation and high volatility - motivates the Markov switching approach adopted. It is also evident that within the two regimes volatility is not constant. Hence the need for a GARCH approach.

\footnotetext{
${ }^{4}$ For a review of the literature on GARCH models see Bera and Higgins (1993) and Bollerslev, Engle and Nelson (1994). More recently, see Hansen and Lunde (2005), who show that a $\operatorname{GARCH}(1,1)$ cannot be outperformed by more sophisticated models in the analysis of exchange rates.
} 


\subsection{Turbulence and Crisis}

The modeling strategy adopted is able to identify turbulent periods. Do turbulent periods correspond to currency crises?

A currency crisis is not necessarily a turbulent period, and vice versa. There can be a crisis without any exchange rate devaluation (and of course without any volatility of the exchange rate devaluation). In fact, the government might be able to absorb exchange rate pressures using foreign reserves, interest rates, etc. On the same base the exchange rate might experience turbulence without being in a crisis.

Citing Kaminsky and Reinhart (1999): "Most often, balance-of-payments crises are resolved through a devaluation of the domestic currency or the flotation of the exchange rate. But central banks can and, on occasion, do resort to contractionary monetary policy and foreign-exchange market intervention to fight speculative attack" (p.475-6).

Figures 1 and 2 provide overwhelming evidence that the 1997 crisis resolved in a large exchange rate devaluation and high volatility. Our modeling approach distinguishes between turbulent and ordinary periods and identifies currency crises only to the extent that they manifest with large exchange rate devaluations.

\section{Time varying probabilities Markov switching GARCH models}

Let $y_{t}$ be the first difference of the log nominal exchange rate. The simple GARCH $(1,1)$ model may be written as follows:

$$
\begin{aligned}
y_{t} & =\mu+\sum_{i=1}^{k} \theta_{i} X_{i, t}+u_{t} \\
u_{t} & =\sigma_{t} \varepsilon_{t}, \varepsilon_{t} \sim n i d(0,1) \\
\sigma_{t}^{2} \mid \Omega_{t-1} & =\omega+\alpha u_{t-1}^{2}+\beta \sigma_{t-1}^{2}
\end{aligned}
$$

where $X_{i}$ are the exogenous and/or lagged variables for the mean of the returns, $\theta$ is the corresponding parameter vector and $\Omega_{t-1}$ is the information set available at time $t-1$. For simplicity we are assuming that the innovation term follows a normal distribution. The model is very flexible, and many extensions have been proposed in the literature.

As shown in the previous section, in periods of currency turbulence, exchange rate volatility is often very high , and we may distinguish between two regimes: a "ordinary" regime and a "turbulence" regime. The approach we adopt here is similar to Gray (1996) and Dueker (1997). Equations 3-5 can be written as 


$$
\begin{aligned}
y_{t} & =\mu_{t}+\sum_{i=1}^{k} \theta_{i} X_{i t}+u_{t} \\
u_{t} & =\sigma_{t} \varepsilon_{t}, \varepsilon_{t} \sim n i d(0,1) \\
\sigma_{t}^{2}\left(S_{t}, S_{t-1} \ldots S_{0}\right) & =\omega\left(S_{t}\right)+\alpha\left(S_{t-1}\right) u_{t-1}^{2}+\beta\left(S_{t-1}\right) \sigma_{t-1}^{2}\left(S_{t-1} \ldots S_{0}\right)
\end{aligned}
$$

The constant, $\mu_{t}$, in the conditional mean equation is allowed to switch between two regimes - high mean $\left(\mu_{1}\right)$ and low mean $\left(\mu_{0}\right)$,

$$
\begin{aligned}
\mu_{t} & =\mu_{1} S_{t}+\mu_{0}\left(1-S_{t}\right) \\
S_{t} & \in\{0,1\}, \quad \forall t \\
\operatorname{Pr}\left(S_{t}=0 \mid S_{t-1}=0\right) & =p \\
\operatorname{Pr}\left(S_{t}=1 \mid S_{t-1}=1\right) & =q
\end{aligned}
$$

where $S_{t}$ is the latent Markov chain of order one. We are assuming that the parameter vector $\theta$ in the conditional mean equation is constant (i.e. it does not switch according to the Markov process), but this assumption can be easily relaxed. The innovation term, $u_{t}$, follows a normal distribution.

The conditional variance, $\sigma_{t}^{2}$, is a function of the entire history of the state variable. This is due to the autoregressive term, $\sigma_{t-1}^{2}$, in the conditional variance equation - see Dueker (1997), Cai (1994) and Hamilton and Susmel (1994). Obviously, it is very demanding to account for all the past history of the state variable. Following Dueker (1997), we adopt an approximation procedure that seems not to cause any problems in the evaluation of the likelihood function. This procedure implies that the conditional variance is a function of only the most recent values of the state variable. Dueker (1997) shows that in a $\operatorname{GARCH}(1,1)$ model we need to consider only the most recent four values of the state variable. This means that the conditional variance, $\sigma_{t}^{2}$, is function only of the current state $\left(S_{t}\right)$ and the previous state $\left(S_{t-1}\right)$ : $\sigma_{t}^{2}(i, j)=\sigma_{t}^{2}\left(S_{t}=i, S_{t-1}=j\right)$. By integrating out $S_{t-1}$, the conditional variance can be written as

$$
\sigma_{t}^{2}(i, j)=\omega\left(S_{t}=i\right)+\alpha\left[u_{t-1}^{2}(j)\right]+\beta\left[\sigma_{t-1}^{2}(j)\right]
$$

Equation (13) implies that the constant in the conditional variance equation is allowed to switch. In the $\operatorname{GARCH}(1,1)$ specification, the unconditional variance is given by $\frac{\omega}{1-\alpha-\beta}$. Therefore, equation (13) allows two unconditional variances: high unconditional variance in "turbulence" regimes and low unconditional variance in "ordinary" regimes. Following Dueker (1997), $\omega\left(S_{t}\right)$ is parameterized as $g\left(S_{t}\right) \omega$ such that $g(S=0)$ is normalized to unity. 
In this setup the transition probabilities are constant. This seems over-restrictive. Transition probabilities may depend on economic variables. For this reason we introduce time varying probabilities. In our setup transition probabilities are probit functions of economic variables denoted by $Z_{t}$

$$
\begin{aligned}
& \operatorname{Pr}\left(S_{t}=0 \mid S_{t-1}=0\right)=p=\Phi\left(Z_{t-1}^{\prime} \zeta\right) \\
& \operatorname{Pr}\left(S_{t}=1 \mid S_{t-1}=1\right)=q=\Phi\left(Z_{t-1}^{\prime} \nu\right)
\end{aligned}
$$

where $\Phi$ denotes the $c d f$ of the normal distribution. A Markov switching regime GARCH model with time varying probabilities is also developed in Gray (1996).

This approach allows forecasting the conditional probability of being in a given regime $(i, j)$ at time $t+1$ given the information available at time $t$.

Denote $\xi_{t \mid t}$ the $(N \times 1)$ vector of conditional probabilities of being in state $(0,1)$ conditional on the data until date $t$. Define $\eta_{t}$ as the $(N \times 1)$ vector of the density of $y_{t}$ conditional on $S_{t}$. Following Hamilton (1994), the optimal forecast for each $t$ is computed by iterating the following two equations

$$
\begin{aligned}
\widehat{\xi}_{t \mid t} & =\frac{\left(\hat{\xi}_{t \mid t-1} \odot \eta_{t}\right)}{\mathbf{1}^{\prime}\left(\hat{\xi}_{t \mid t-1} \odot \eta_{t}\right)} \\
\widehat{\xi}_{t+1 \mid t} & =\mathbf{P}_{t+1} \cdot \hat{\xi}_{t \mid t}
\end{aligned}
$$

where $\mathbf{1}$ is the unit vector, $\mathbf{P}_{t+1}$ is the $(N \times N)$ Markov transition probability matrix and $\odot$ denotes the element-by-element multiplication.

Recall that $\mathbf{P}_{t}$ is time varying and depends on the previous period values of explanatory variables. We are mainly interested in the turbulent regime. Our approach allows us to compute the probability of moving to a turbulence regime in period $t+1$ given all the available information at time $t$.

The log-likelihood function is given by

$$
\ln L_{t}(i, j)=-\frac{1}{2} \ln \left[\sigma_{t}^{2}(j)\right]+\ln \left[\frac{u_{t-1}^{2}(i)}{\sigma_{t}^{2}(j)}\right]-\ln [\sqrt{2 \pi}]
$$

where $i \in\{0,1\}$ relates to $S_{t} \in\{0,1\}$ and $j \in\{0,1\}$ relates to $S_{t-1} \in\{0,1\}$. The function is maximized following Hamilton (1994). 


\section{Data Description}

Currency crises/turmoil most often reveal themselves in an actual devaluation of the domestic currency or the flotation of the exchange rate. Nevertheless, there are occasions in which central banks wind up adopting contractionary policies. In these cases, crises manifest themselves in interest rate hikes, depletion of reserves, etc. Also, currency crises are sometimes linked to banking/financial sector distresses. ${ }^{5}$

To take into account all facets of currency turmoil, we consider a number of macroeconomic and financial variables: M2/reserves, real domestic credit, real effective exchange rate, banking sector stock index returns and volatility, general stock market index returns and volatility. ${ }^{6}$ In order to get a clearer view of the evolution of turbulent periods we use monthly data, from November 1984 to December 2001. ${ }^{7}$

Exchange rates devaluation/appreciation is simply computed using end of the month log-first difference.

Real effective exchange rate (REER) and interest rate differentials (IRDIFF) are external sector indicators. In particular, the percentage deviation of the REER from a trend is a current account indicator, while the domestic-US real interest rate differential on deposits represents an indicator associated with the capital account. REER is considered as deviation from a trend because not all real appreciations/depreciations necessarily reflect disequilibrium phenomena.

M2/reserves (M2 ratio) together with real domestic credit/GDP (RDC) are financial sector indicators. Both variables are considered in deviation from a trend. In fact, not all the changes in those indicators are symptomatic of a troublesome situation. ${ }^{8}$

Stock index returns (GENRET) and volatility (GENVOL) are indicators of the real sector ${ }^{9}$ linking currency turmoil to economic activity.

In order to stress the link between currency crises and banking problems we introduce returns and volatility of a stock index based on a portfolio (weighted by the capitalization) of banks listed on the stock market (BANKRET and BANKVOL, respectively). ${ }^{10}$ We believe these variables could be important indicators for the Southeast Asian crisis we study in this paper.

Citing Kaminsky and Reinhart, "Of course, this is not an exhaustive list of potential indicators" (p.481). We have considered only some of the indicators that they suggest and add

\footnotetext{
${ }^{5}$ For a literature review on the link between banking and currency crisis see Kaminsky and Reinhart (1999).

${ }^{6}$ See appendix for a description of how those series were created.

${ }^{7}$ The dataset consists of ex-post revised data. A forecasting exercise should be performed with real-time data.

${ }^{8}$ Trend components are computed using the Hodrick-Prescott filter. If this model were to be used for forecasting purposes, a one-sided filter should be use, so that only past information would be considered in the determination of the trend.

${ }^{9}$ The classification of these variables as external, financial and real sector indicators is based on Kaminsky and Reinhart (1999). They do not include any volatility measures as possible indicators.

${ }^{10}$ The volatility of the general stock market index and the volatility of the banking index are computed using the range - equations (1) and (2).
} 
some others, based on the empirical evidence of the countries that we analyze. However, Edison (2000) suggests that a marked appreciation of the real exchange rate, a high ratio of short-term debt to reserves, a high ratio of M2 to reserves, substantial losses of foreign exchange reserves, and sharply declining equity prices represent the more important indicators of vulnerability.

Figure 3-6 display the evolution of the above indicators for Thailand, Singapore, Philippines and Malaysia.

In all the countries the real effective exchange rate is appreciating relative to its trend during the period before the onset of the 1997 crisis, showing evidence of overvaluation. (Note that the real effective exchange rate follows the UK quotation - i.e. US Dollars per local currency.) For Thailand, the Philippines and Malaysia the REER is 9-10\% above the trend in the 12 months preceding the crisis. This is in line with previous literature on currency crises. Domestic-US real interest rate differentials do not indicate any rising expectations of devaluation as the 1997 currency crisis approaches. For all the countries analyzed, in the 12 months before the crisis, IRDIFFs are flat.

Turning now to the financial sector variables, it is possible to note that in Thailand and Malaysia the M2/reserves deviation from trend is positive and significative in size during the period before the onset of the 1997 crisis. This is in line with both a large expansion in M2 and a sharp decline in foreign currency reserves as also pointed out in Kaminsky and Reinhart (1999) for banking and currency crises. In Singapore and Philippines the M2 ratio does not display any considerable deviation from trend.

RDC is above its trend before the 1997 crisis in the Philippines and Malaysia but it is around trend in Thailand and Singapore.

The returns on the stock market index in the 12 months before the 1997 crisis are, on average, negative for all the markets considered. Particularly severe is the drop in the general stock market index in Thailand: the monthly return averages to $-7 \%$. Stock market volatility is also very high. The stock market represents the real sector; therefore, the stock market returns volatility may be interpreted as the uncertainty/risk related to the real sector. In the twelve months before the crisis, stock market volatility in Thailand doubles with respect to the average value over the whole sample. Also for Singapore, the Philippines and Malaysia stock market volatility increases.

Currency crises are sometimes evidence of banking sector distress. For this reason we use the banking sector index. In Thailand, the average monthly return of the banking sector is $-8 \%$ in the 12 months before July 1997. Evidence of banking sector distress is also present in Singapore and Malaysia. In Thailand, the volatility of the banking index return more than doubles in the months before the crisis. Similar results hold for Singapore and Malaysia, but not for the Philippines. $^{11}$

\footnotetext{
${ }^{11}$ We computed summary statistics for all the variables analyzed. However, to conserve space we do not report
} 


\section{$5 \quad$ Empirical Results}

For each country we estimated several models. To distinguish among models we use the number of explanatory variables in the time varying Markov probabilities. We started from the Switching Regime GARCH with constant transition probabilities. This is "Model(1,1)" because it includes only a constant for each probability. The model including an explanatory variable in the time varying Markov probability of the "ordinary" state $(p)$ is referred to as "Model $(2,1)$ " because there is a constant plus an explanatory variable in $p$ and only a constant in $q$.

To select among the different models we use the following criteria:

1. Analysis of the statistical properties of the estimated parameters - i.e. parameters should be well-determined. In this regard, it is important to note that GARCH models, to work properly, require many data points. Unfortunately, the use of monthly frequencies is problematic in this respect. For this reason we consider $90 \%$ significance level.

2. The estimated coefficients in the probit representation of the time varying probabilities should have the right sign so that they can have a proper economic interpretation;

3. Transition probabilities: if the model delivers an increase in the probability of getting into the turbulent regime before the onset of the turbulence, we will consider the model as satisfactory. All the turbulent periods in the data set will be considered. However, we will pay particular attention to the 1997 crisis;

4. Models will be compared in terms of the value of the Akaike (AIC) and Schwartz (SIC) information criteria.

In what follows we analyze the estimation results and the transition probabilities of the estimated models. ${ }^{12}$ We report both the graph of the filtered transition probabilities and tables showing the behavior of these probabilities over turbulent periods. Providing a formal definition of turbulent periods is beyond the scope of this paper. We identify turbulent periods with severe devaluations. Tables reporting the time-varying probabilities aim to provide evidence about the performance of the estimated models.

Our analysis of the empirical results starts from Thailand, the first country involved in the 1997 crisis.

${ }^{12}$ To conserve space we only report results and charts for the model we selected using criteria $1-4$ above, and we report also Model $(1,1)$ for comparison.
} 


\subsection{Thailand}

\subsubsection{Estimation Results}

Table 1 reports the selected models for Thailand. For comparison we also report the simple Model $(1,1)$ where the Markov probabilities are constant. The simple Model $(1,1)$ reveals the average exchange rate devaluation during "ordinary" market conditions is not statistically different from zero and it is associated with a very low volatility (variance) level. In the "turbulence" state the average devaluation jumps to $9 \%$ (per month) which is associated with a volatility level which is more than 500 times bigger than the "ordinary" state. The GARCH parameters, $\alpha$ and $\beta$, are statistically well-defined and in line with the values reported in the literature on exchange rate volatility. In the third column of Table 1 we report the estimated parameters for Model $(2,1)$. This model is characterized by the fact that REER is added as an explanatory variable in $p$, the probability of being in the ordinary state at $t+1$ given the information available at time $t$. As for the simple Model $(1,1)$ the two regimes are evident: low devaluation goes with low volatility and high devaluation goes with high volatility. Interestingly, in the conditional variance equation, $\alpha$ is negative. Nevertheless the conditional variance is always positive ${ }^{13}$ - this is also true for Model $(3,1)$. REER is significant and has the correct sign. Well before the onset of the crises the REER is moving as to anticipate the forthcoming exchange rate devaluation.

Model $(3,1)$ contains REER and M2 ratio as explanatory variables in $p$ while $q$ contains only a constant. Both indicators have the correct sign and are significant. For this model, the volatility in the turbulent regime shifts by a factor of 715 . Finally, the two indicators in the last model are REER and the banking index returns. BANKRET has a positive sign. In fact, when the banking sector is performing well (positive returns), the probability of staying in the ordinary state increases. Notice that, for the last model, we were forced to use less observations because the data on the banking index starts in February 1987. AIC and SIC select Model(3,1) with REER and BANKRET as explanatory variables in $p$.

\subsubsection{Time-Varying Transition Probabilities}

For Thailand, in the period analyzed, the major turbulence was due to the 1997 crisis, which started in July. Table 2 contains the transition probabilities of getting into a turbulent period at time $t+1$, given the available information up until time $t$ (equation 17), for the selected models - see Table 1.

The second row shows the average of that probability during ordinary periods. The simple Model(1,1) is able neither to anticipate nor to provide any warning of the $1997 \mathrm{crisis}$. The situation changes when considering $\operatorname{Model}(2,1)$. In June 1997, Model $(2,1)$ gives a $14 \%$ probability

\footnotetext{
${ }^{13}$ See Nelson and Cao (1992).
} 
of getting into a crisis in the next month. In absolute terms, the value of $14 \%$ is not high. However, in relative terms - i.e. when compared to the average probability in tranquil periods - $14 \%$ represents a noticeable jump in the probability level. When we include the M2 ratio and the BANKRET the June 1997 probability of getting into a crisis in the next period jumps to $34 \%$ and $82 \%$, respectively.

Figure 7 shows the transition probabilities of the last two models in Table 1. Signals of the 1997 crisis are already apparent in January 1997. We consider this a very good result.

For Thailand the indicators that proved to be important are REER, M2 ratio and bank index returns. It is interesting to note that all the models selected contain the REER as an explanatory variable. Moreover, all models have just a constant in $q$ - the probability of moving from turbulence to ordinary regime - while all the action is in $p$ - the probability of moving from an ordinary regime to a turbulent one.

\subsection{Singapore}

\subsubsection{Estimation Results}

Table 3 reports the five selected models for Singapore. The simple Model $(1,1)$ reveals that the exchange rate devaluation exhibits two regimes. In the ordinary regime the currency is, on average, appreciating and the volatility is low. In the turbulent regime the currency is depreciating and the volatility shifts by a factor of 6 . The parameter $\beta$ in the GARCH specification is not significantly different from zero. Therefore, all the models in Table 3 follow an ARCH(1) specification. Model $(2,1)$ includes REER in $p$. All the parameters are well-defined. If REER is appreciating, the probability of being in the ordinary period decreases while the probability of being in the turbulent regime increases. This is the reason why in Model $(2,2)$ the REER coefficient is negative in $p$ and positive in $q$. For Singapore, both the banking index returns and the banking index return volatility are important indicators (jointly with REER). They indeed display the expected sign and are significant. AIC selects Model(3,1) with REER and banking index returns as explanatory variables in $p$, while SIC selects Model $(2,1)$ with REER only as an explanatory variable in $p$.

\subsubsection{Time-Varying Transition Probabilities}

Transition probabilities of the selected models for Singapore are reported in Table 4. We identify three periods of turbulence. The more severe turbulent period coincides with the 1997 crisis, which started in August. The other two turbulent periods are April and October 2001.

Model $(2,1)$ shows that the June 1997 probability to move to a turbulent period in $t+1$ (July) is $35 \%$. This probability is $57 \%$ in the next period. Model $(2,2)$ performs even better: in June 1997 the probability of getting into turbulence in $t+1$ is $55 \%$. Models which include 
the banking return index and the banking return index volatility perform well in detecting all turbulent periods.

Figure 8 graphs the transition probabilities of $\operatorname{Model}(2,2)$ with REER in both $p$ and $q$, and Model(3,1) with REER and BANKVOL in $p$. It is evident how both models are able to reveal signs of the turbulent periods experienced by the Singapore dollar. Model(3,1) with REER and BANKVOL already shows symptoms of the 1997 crisis in February 1997.

Real effective exchange rate, bank index returns and volatility are the important indicators for Singapore. Model $(2,2)$ indicates that REER is important in modeling both the probability of being in the ordinary regime and staying in that regime and the probability of being in a turbulent regime and staying in that regime. This is the only model, for all the countries analyzed, where it is important to model $q$ - i.e. $q$ is not constant but varies over time. Combining REER and banking indicators in modeling $p$ produces very interesting results.

\subsection{The Philippines}

\subsubsection{Estimation Results}

For the Philippines, the parameter $\beta$ in the conditional variance equation is not statistically important; therefore, the models analyzed reduce to an ARCH specification. Table 5 contains the three selected models. In Model $(1,1)$ all the coefficients are significant at standard significance level. The only two indicators that are important for this country are REER and general stock index returns. The real effective exchange rate in $\operatorname{Model}(2,2)$ has the expected negative sign, but it is not statistically important. REER is also not significant in $\operatorname{Model}(3,1)$. However, model $(1,1)$ is selected by both AIC and SIC.

\subsubsection{Time-Varying Transition Probabilities}

The transition probabilities of the three selected models for the Philippines are reported in Table 6. We distinguish four turbulence periods: November 1990, the 1997 crisis that started in July, July 2000, and April 2001. The simple Model(1,1) performs as well as the other models in identifying the turbulent periods.

Figure 9 shows the transition probabilities for the last two models in table 5 . The exchange rate devaluation of the Philippine peso is very volatile and shows several periods of appreciation/depreciation. The probabilities exhibit a similar pattern.

Despite sound economic fundamentals (see Figure 5 ) both REER and GENRET are gathering signs of the forthcoming turmoil. 


\subsection{Malaysia}

\subsubsection{Estimation Results}

The last country analyzed is Malaysia. The data sample is shortened to account for the pegging regime that started in November 1998. Table 7 reports the four selected models. Model $(2,1)$ shows that REER has the correct sign and is significant. This is in line with the evidence provided for the other countries. The M2 ratio ${ }^{14}$ reveals to be an important indicator, and the bank index return standard deviation also provides very interesting results. AIC and SIC select Model(3,1) with REER and BANKVOL as explanatory variables in $p .^{15}$

\subsubsection{Time-Varying Transition Probabilities}

We identify three periods of turbulence: January 1994, August 1997, ${ }^{16}$ and May 1998. All models, but Model(1,1), already show in June 1997 the limbo of the crisis. The performance in anticipating the 1997 crisis is spectacular for two models: Model(3,1) with REER and M2 ratio, and Model $(3,1)$ with REER and BANKVOL. These results are confirmed by Figure 10.

\subsection{Summary of the Empirical Results}

The results for all the countries analyzed show interesting common features. First, modeling $p$ as time varying produces the best results. Our intuition relies on the fact that $(1-p)$ gives the probability of getting into turbulence from the ordinary regime. In our methodology $(1-p)$ represents the first channel through which changes in the explanatory variables affect the transition probabilities.

Real effective exchange rate displays an enormous explanatory power in all the countries. In addition, M2 ratio, BANKRET, BANKVOL, GENRET contain valuable information which improves the performance of the models.

\section{Conclusions}

In this paper we adopt a GARCH Markov switching regime model. The approach consists of jointly modeling the conditional mean and the conditional variance of exchange rate changes. The estimated parameters confirm the importance of modeling volatility dynamics. Stock market and banking sector indexes, together with real effective exchange rates and M2 ratios, play an important role in understanding exchange rate turbulence.

\footnotetext{
${ }^{14}$ For Malaysia, the first difference of the M2 ratio is used. The deviation from trend for M2 ratio was very noisy.

${ }^{15}$ Data on the bank stock index are available only from February 1986.

${ }^{16}$ As in Kaminsky and Reinhart (1999) we identify the onset of the Malaysian crisis with August 1997.
} 
Our approach exhibits several limitations. It is not applicable to countries that are pegging their exchange rate. In fact, in this case, there will not be any variation of the exchange rate and any volatility of the exchange rate. Moreover, we are only able to distinguish turbulent and ordinary regimes. As already discussed, turbulence does not always coincide with currency crises. Finally, we consider only four countries and a major currency crisis. It remains to validate how this methodology would work with other countries and other currency crises. However, an advantage of this approach is that it could be easily used for out-of-sample forecasting, which we leave for further research.

\section{Appendix}

\subsection{Data}

We created a data set for Malaysia, the Philippines, Singapore and Thailand composed of five variables: exchange rate return/devaluation, M2 ratio, real domestic credit/GDP, real effective exchange rate devaluation, domestic-US real interest rate differential on deposits, stock index returns and volatility, banking sector return and volatility.

All data, with the exception of the real effective exchange rate and stock index and banking sector index, are retrieved from the International Financial Statistics (IFS) database. The real effective exchange rate is from JP Morgan, while stock data are from Bloomberg.

All the variables are constructed accordingly with the literature on currency crises. See Kaminsky and Reinhart (1999).

M2 ratio is given by the sum of M1 (IFS line 24) and quasi money (IFS line 25) divided by Reserves (IFS line 1l.d) converted into national currency.

Real domestic credit is domestic credit (IFS line 52) divided by CPI (IFS line 64) to obtain domestic credit in real terms and then divided by GDP (IFS line 99b.p.). Monthly GDP is obtained by interpolating quarterly data.

Interest rate differentials are computed as the difference between domestic and US real interest rates on deposits. Real rates are deposit rates (IFS line 60) deflated using consumer prices (IFS line 64).

The real effective exchange rate is a measure of competitiveness and rises if for example domestic inflation exceeds that abroad and the nominal exchange rate fails to depreciate to compensate.

General stock index returns are first difference of the natural logarithm of the stock index.

General index returns volatility is computed using equations (1) and (2).

Banking index returns are first difference of the natural logarithm of the banking index.

Banking index returns volatility is computed using equations (1) and (2). 


\section{References}

[1] Baillie, R.T. and Bollerslev, T. (1989), "The Message in Daily Exchange Rates: A Conditional Variance Tale," Journal of Business and Economic Statistics, 7, 297-305.

[2] Bera, A. K., and M. L., Higgins (1993), "ARCH Models: Properties, Estimation and Testing," Journal of Economic Surveyes, 7, 305 - 362.

[3] Berg, A. and Pattillo, C. (1999a), "Are Currency Crises Predictable? A Test," IMF Staff Papers, 46-2, 107-138.

[4] Berg, A. and Pattillo, C. (1999b), "Predicting Currency Crises: The Indicators Approach and An Alternative," Journal of International Money and Finance, 18-4, 561-586.

[5] Bollerslev, T., Engle, R.F. and Nelson, D.B. (1994), "ARCH Models," in Handbook of Econometrics, Volume IV, 2959-3038, eds. R.F. Engle and D. McFadden, Amsterdam: North-Holland.

[6] Brunetti, C. and Lildholdt, P. (2002a), "Return-based and range-based (co)variance estimation - with an application to foreign exchange markets," Mimeo, Univeristy of Pennsylvania.

[7] Brunetti, C. and Lildholdt, P. (2002b), "Time Series Modeling of Daily Log-price Ranges for the SF/USD and USD/GBP," PIER Working Paper 02-017.

[8] Bussiere, M. and Fratzscher, M. (2006), "Towards a new early warning system of financial crises," Journal of International Money and Finance, 25, 953-973

[9] Cai, J. (1994), "A Markov model of switching-regime ARCH," Journal of Business E3 Economic Statistics, 12, 309-316.

[10] Calvet, L., and Fisher A. (2004), "How to Forecast Long-Run Volatility: Regime-Switching and the Estimation of Multifractal Processes," Journal of Financial Econometrics 2, 49-83.

[11] Chou, R. (2005), "Forecasting financial volatilities with extreme values: The conditional autoregressive range (CARR) model," Journal of Money, Credit, and Banking, 37, 561-582.

[12] Corsetti, G., Pesenti, P. and Roubini, N. (1999), "Paper Tigers? A Model of the Asian Crisis," European Economic Review, 43, 1211-1236.

[13] Ding, Z., Granger, C. and Engle, R. (1993), "A long memory property of stock returns and a new model," Journal of Empirical Finance 1, 83-106.

[14] Dueker, M.J. (1997), "The Econometrics of Ultra-High Frequency Data," Journal of Business and Economic Statistics, 15-1, 26-34. 
[15] Edison, H.J. (2002), "Do Indicators of Financial Crises Work? An Evaluation of An Early Warning System," International Journal of Finance and Economics, 8, 11-53.

[16] Eichengreen, B., Rose, A. and Wyplosz, C. (1994), "Speculative Attacks on Pegged Exchange Rates: An Empirical Exploration With Special Reference to the European Monetary System," NBER Working Paper, Cambridge, Massachusetts: National Bureau of Economic Research, No.4898.

[17] Eichengreen, B., Rose, A. and Wyplosz, C. (1995), "Exchange Market Mayhem: The Antecedents and After-math of Speculative Attacks," Economic Policy, October, 249-312.

[18] Eichengreen, B., Rose, A. and Wyplosz, C. (1996), "Contagious Currency Crises: First Tests," Scandinavian Journal of Economics, 98, 463-484.

[19] Fama, E.F. (1965), "The Behaviour of Stock Market Prices," Journal of Business, 38, 34 105.

[20] Feller, W. (1951), "Two Singular Diffusion Problems," Annals of Mathematics 54, 173-182.

[21] Frankel, J. and Rose, A. (1996), "Currency Crashes in Emerging Markets: An Empirical Treatment," International Finance Discussion Papers, Board of Governors of the Federal Reserve System, 534 .

[22] Goldstein, G., Kaminsky, L. and Reinhart, C.M. (2000), "Assessing Financial Vulnerability: An Early Warning System for Emerging Markets," Washington: Institute for International Economics.

[23] Gray, S.F. (1996), "Modeling the conditional distribution of interest rates as a regimeswitching process," Journal of Financial Economics, 42, 27-62.

[24] Hamilton, J. (1994), Time Series Analysis, Princeton University Press, Princeton.

[25] Hamilton, J.D. Susmel, R. (1994), "Autoregressive Conditional Heteroskedasticity and Changes in Regime," Journal of Econometrics, 64(1-2), 307-33.

[26] Hansen, P.R. and Lunde, A. (2005), "A Forecast Comparison of Volatility Models: Does Anything beat a GARCH(1,1)?," Journal of Applied Econometrics, 20, 873-889.

[27] IMF (1998), "World Economic Outlook," Washington D.C.: International Monetary Fund, May.

[28] Kalimipalli, M., and Susmel, R. (2006), "Switching Stochastic Volatility and the Short-Term Interest Rates," Journal of Empirical Finance, forthcoming. 
[29] Kaminsky, G. (1998a), "Currency and Banking Crises: A Composite Leading Indicator," IMF Seminar Series, 6.

[30] Kaminsky, G. (1998b), "Financial Crises in Asia and Latin America: Then and Now," American Economic Review, Papers and Proceedings, 88, 44-48.

[31] Kaminsky, G., Lizondo, S. and Reinhart, C.M. (1998), 'Leading Indicators of Currency Crises', IMF Staff Papers, March.

[32] Kaminsky, G. and Reinhart, C.M. (1999), "The Twin Crises: The Causes of Banking and Balance-of-Payment Problems," American Economic Review, 89, 473-500.

[33] Kaminsky, G. and Schmukler, S. (1999), "What triggers market jitters? A chronicle of the Asian crisis," Journal of International Money and Finance, 18, 537-560.

[34] Klaassen, F. (2002), "Improving GARCH Volatility Forecasts with Regime-Switching GARCH," Empirical Economics, 27, 363-394.

[35] Kumar, M.S., Moorthy, U. and Peraudin, W. (2003), "Predicting Emerging Market Currency Crashes," Journal of Empirical Finance, 10, 427-454.

[36] Mandelbrot, B. (1963a), "The Variation of Certain Speculative Prices," Journal of Business, $36,394-419$.

[37] Mandelbrot, B. (1963b), "New Methods in Statistical Economics," Journal of Political Economy, 71, 421 - 440 .

[38] Mariano, R.S., Abiad, A.G., Gultekin, B., Shabbir, T. and Tan, A. (2002), "Markov Chains In Predictive Models of Currency Crises - With Applications to Southeast Asia," PIER Working Paper 02-013.

[39] Nelson, D.B. and Cao,C.Q. (1992), "Inequality Constraints in the Univariate GARCH Model," Journal of Business and Economic Statistics, 10, 229 - 235.

[40] Parkinson, M. (1980), "The Extreme Value Method for Estimating the Variance of the Rate of Return," Journal of Business, 53, 61-65.

[41] Radelet, S. and Sachs, J. (1998), "The East-Asian Financial Crisis: Diagnosis, Remedies, Prospects," Brookings Papers on Economic Activity, 1, p.1-90.

[42] Sachs, J., Tornell, A. and Velasco, A. (1996), "Financial Crises in Emerging Markets: The Lessons From 1995," Brookings Papers on Economic Activity, 1, 147-215. 
[43] Susmel, R. (1998), "Switching Volatility in Latin American Emerging Markets," Emerging Markets Quarterly, 2, 44-56.

[44] Susmel, R. (2000), "Switching Volatility in International Equity Markets," International Journal of Finance and Economics, 5, 265-283.

[45] Tan, A.H.H. (1999), "The Asian Economic Crisis: The Way Ahead For Singapore," Chapter 2 in Singapore Inc., Public Policy Options In The Third Millennium, edited by Linda Low \& Douglas Johnston, Asia Pacific Press, Singapore, 2001, pp.17-34.

[46] Tornell, A. (1999), "Common Fundamentals in the Tequila and Asian Crises," NBER Working Paper, No. 7139. 


\begin{tabular}{|c|c|c|c|c|}
\hline Thailand & Model $(1,1)$ & $\begin{array}{c}\text { Model }(2,1) \\
\text { REER }\end{array}$ & $\begin{array}{c}\text { Model }(3,1) \\
\text { REER } \\
\text { M2ratio }\end{array}$ & $\begin{array}{c}\text { Model }(3,1) \\
\text { REER } \\
\text { BANKRET }\end{array}$ \\
\hline$\mu_{0}$ & $\begin{array}{c}-0.002 \\
(0.036)\end{array}$ & $\begin{array}{c}-0.005 \\
(0.042)\end{array}$ & $\begin{array}{c}-0.119 \\
(0.039)\end{array}$ & $\begin{array}{l}0.010 \\
(0.042)\end{array}$ \\
\hline$\mu_{1}$ & $\begin{array}{l}9.380 \\
(2.291)\end{array}$ & $\begin{array}{l}6.983 \\
(2.424)\end{array}$ & $\begin{array}{l}6.773 \\
(2.425)\end{array}$ & $\begin{array}{l}4.227 \\
(2.90)\end{array}$ \\
\hline$\omega$ & $\begin{array}{l}0.023 \\
(0.007)\end{array}$ & $\begin{array}{c}0.04 \\
(0.006)\end{array}$ & $\begin{array}{l}0.034 \\
(0.005)\end{array}$ & $\begin{array}{l}0.049 \\
(0.014)\end{array}$ \\
\hline$g$ & $\begin{array}{l}597.844 \\
(414.207)\end{array}$ & $\begin{array}{l}525.816 \\
(103.844)\end{array}$ & $\begin{array}{l}715.100 \\
(164.832)\end{array}$ & $\begin{array}{l}488.721 \\
(323.025)\end{array}$ \\
\hline$\alpha$ & $\begin{array}{l}0.093 \\
(0.045)\end{array}$ & $\begin{array}{c}-0.047 \\
(0.027)\end{array}$ & $\begin{array}{c}-0.0509 \\
(0.021)\end{array}$ & $\begin{array}{l}0.168 \\
(0.092)\end{array}$ \\
\hline$\beta$ & $\begin{array}{l}0.804 \\
(0.046)\end{array}$ & $\begin{array}{l}0.849 \\
(0.027)\end{array}$ & $\begin{array}{l}0.873 \\
(0.018)\end{array}$ & $\begin{array}{c}0.6182 \\
(0.072)\end{array}$ \\
\hline$p-$ const & $\begin{array}{l}2.364 \\
(0.268)\end{array}$ & $\begin{array}{l}2.378 \\
(0.314)\end{array}$ & $\begin{array}{l}2.852 \\
(0.538)\end{array}$ & $\begin{array}{l}6.839 \\
(3.856)\end{array}$ \\
\hline$p-R E E R$ & & $\begin{array}{c}-0.117 \\
(0.066)\end{array}$ & $\begin{array}{c}-0.168 \\
(0.084)\end{array}$ & $\begin{array}{c}-0.332 \\
(0.216)\end{array}$ \\
\hline$p-M 2$ ratio & & & $\begin{array}{c}-0.725 \\
(0.695)\end{array}$ & \\
\hline$p-B A N K R E T$ & & & & $\begin{array}{l}0.189 \\
(0.121)\end{array}$ \\
\hline$q-$ const & $\begin{array}{l}1.809 \\
(0.755)\end{array}$ & $\begin{array}{l}0.929 \\
(0.499)\end{array}$ & $\begin{array}{l}1.362 \\
(0.539)\end{array}$ & $\begin{array}{l}0.226 \\
(0.870)\end{array}$ \\
\hline$\theta$ & $\begin{array}{l}0.237 \\
(0.064)\end{array}$ & $\begin{array}{l}0.298 \\
(0.062)\end{array}$ & $\begin{array}{l}0.272 \\
(0.065)\end{array}$ & $\begin{array}{l}0.282 \\
(0.074)\end{array}$ \\
\hline AIC & 2.6010 & 2.6058 & 2.5873 & 2.2849 \\
\hline SIC & 2.7469 & 2.7680 & 2.7656 & 2.4636 \\
\hline
\end{tabular}

Table 1: Thailand - Estimation Results 


\begin{tabular}{cccccc}
\hline Thailand & ERDEV & Model(1,1) & $\begin{array}{c}\text { Model(2,1) } \\
\text { RERR }\end{array}$ & $\begin{array}{c}\text { Model }(3,1) \\
\text { RERR } \\
\text { M2ratio }\end{array}$ & $\begin{array}{c}\text { Model(3,1) } \\
\text { REER } \\
\text { BANKRET }\end{array}$ \\
\hline \multirow{2}{*}{$\begin{array}{c}\text { ordinary } \\
\text { period }\end{array}$} & 0.078 & 0.02 & 0.03 & 0.03 & 0.02 \\
average & & & & & \\
& & & & & \\
Jun-1997 & -0.35 & 0.01 & 0.14 & 0.37 & 0.82 \\
Jul-1997 & 16.22 & 0.96 & 0.82 & 0.91 & 0.53 \\
Aug-1997 & 6.88 & 0.92 & 0.54 & 0.77 & 0.62 \\
Sep-1997 & 11.12 & 0.94 & 0.77 & 0.88 & 0.40 \\
Oct-1997 & 2.99 & 0.83 & 0.50 & 0.72 & 0.17 \\
Nov-1997 & 4.96 & 0.77 & 0.37 & 0.62 & 0.08 \\
Dec-1997 & 14.19 & 0.93 & 0.68 & 0.80 & 0.26 \\
Jan-1998 & 17.24 & 0.95 & 0.75 & 0.85 & 0.27 \\
\hline
\end{tabular}

Table 2: Thailand - Transition Probabilities 


\begin{tabular}{|c|c|c|c|c|c|}
\hline Singapore & Model(1,1) & $\begin{array}{c}\text { Model }(2,1) \\
\text { REER }\end{array}$ & $\begin{array}{c}\text { Model }(2,2) \\
\text { REER } \\
\text { REER }\end{array}$ & $\begin{array}{c}\text { Model }(3,1) \\
\text { REER } \\
\text { BANKRET }\end{array}$ & $\begin{array}{c}\text { Model }(3,1) \\
\text { REER } \\
\text { BANKVOL }\end{array}$ \\
\hline$\mu_{0}$ & $\begin{array}{c}-0.141 \\
(0.078)\end{array}$ & $\begin{array}{c}-0.156 \\
(0.081)\end{array}$ & $\begin{array}{c}-0.192 \\
(0.078)\end{array}$ & $\begin{array}{c}-0.148 \\
(0.077)\end{array}$ & $\begin{array}{c}-0.135 \\
(0.772)\end{array}$ \\
\hline$\mu_{1}$ & $\begin{array}{l}0.348 \\
(0.377)\end{array}$ & $\begin{array}{l}0.375 \\
(0.370)\end{array}$ & $\begin{array}{l}0.450 \\
(0.301)\end{array}$ & $\begin{array}{l}0.229 \\
(0.291)\end{array}$ & $\begin{array}{l}0.208 \\
(0.315)\end{array}$ \\
\hline$\omega$ & $\begin{array}{l}0.725 \\
(0.123)\end{array}$ & $\begin{array}{l}0.698 \\
(0.120)\end{array}$ & $\begin{array}{l}0.677 \\
(0.110)\end{array}$ & $\begin{array}{l}0.591 \\
(0.105)\end{array}$ & $\begin{array}{l}0.626 \\
(0.113)\end{array}$ \\
\hline$g$ & $\begin{array}{l}6.37 \\
(2.375)\end{array}$ & $\begin{array}{l}5.723 \\
(2.102)\end{array}$ & $\begin{array}{l}4.710 \\
(1.388)\end{array}$ & $\begin{array}{l}5.741 \\
(1.679)\end{array}$ & $\begin{array}{l}5.906 \\
(1.866)\end{array}$ \\
\hline$\alpha$ & $\begin{array}{l}0.153 \\
(0.147)\end{array}$ & $\begin{array}{l}0.191 \\
(0.146)\end{array}$ & $\begin{array}{l}0.239 \\
(0.126)\end{array}$ & $\begin{array}{l}0.222 \\
(0.129)\end{array}$ & $\begin{array}{l}0.190 \\
(0.133)\end{array}$ \\
\hline$p-$ const & $\begin{array}{l}2.067 \\
(0.336)\end{array}$ & $\begin{array}{l}2.615 \\
(0.775)\end{array}$ & $\begin{array}{l}2.950 \\
(0.895)\end{array}$ & $\begin{array}{l}4.683 \\
(3.789)\end{array}$ & $\begin{array}{l}3.656 \\
(1.794)\end{array}$ \\
\hline$p-R E E R$ & & $\begin{array}{c}-0.523 \\
(0.365)\end{array}$ & $\begin{array}{c}-0.590 \\
(0.406)\end{array}$ & $\begin{array}{l}-0.932 \\
(-0.943)\end{array}$ & $\begin{array}{c}-0.662 \\
(0.508)\end{array}$ \\
\hline$p-B A N K R E T$ & & & & $\begin{array}{l}0.369 \\
(0.295)\end{array}$ & \\
\hline$p-B A N K V O L$ & & & & & $\begin{array}{c}-0.182 \\
(0.110)\end{array}$ \\
\hline$q-$ const & $\begin{array}{l}1.294 \\
(0.453)\end{array}$ & $\begin{array}{l}1.275 \\
(0.431)\end{array}$ & $\begin{array}{l}2.182 \\
(1.507)\end{array}$ & $\begin{array}{l}1.004 \\
(0.335)\end{array}$ & $\begin{array}{l}1.108 \\
(0.379)\end{array}$ \\
\hline$q-R E E R$ & & & $\begin{array}{l}0.481 \\
(0.487)\end{array}$ & & \\
\hline$\theta$ & $\begin{array}{l}0.267 \\
(0.074)\end{array}$ & $\begin{array}{l}0.256 \\
(0.074)\end{array}$ & $\begin{array}{l}0.240 \\
(0.073)\end{array}$ & $\begin{array}{l}0.282 \\
(0.073)\end{array}$ & $\begin{array}{l}0.276 \\
(0.073)\end{array}$ \\
\hline $\mathrm{AIC}$ & 3.1961 & 3.1727 & 3.1805 & 3.1668 & 3.1815 \\
\hline SIC & 3.3258 & 3.3186 & 3.3426 & 3.3290 & 3.3436 \\
\hline
\end{tabular}

Table 3: Singapore - Estimation Results 


\begin{tabular}{|c|c|c|c|c|c|c|}
\hline Singapore & ERDEV & $\operatorname{Model}(1,1)$ & $\begin{array}{c}\text { Model }(2,1) \\
\text { REER }\end{array}$ & $\begin{array}{c}\text { Model }(2,2) \\
\text { REER } \\
\text { REER }\end{array}$ & $\begin{array}{c}\text { Model }(3,1) \\
\text { REER } \\
\text { BANKRET }\end{array}$ & $\begin{array}{c}\text { Model }(3,1) \\
\text { REER } \\
\text { BANKVOL }\end{array}$ \\
\hline & & \multicolumn{5}{|c|}{ Transition Probabilities $\left(P_{t \mid t-1}\right)$} \\
\hline $\begin{array}{c}\text { ordinary } \\
\text { period } \\
\text { average }\end{array}$ & 0.15 & 0.04 & 0.14 & 0.15 & 0.09 & 0.13 \\
\hline Jun-1997 & -0.70 & 0.03 & 0.35 & 0.55 & 0.37 & 0.30 \\
\hline Jul-1997 & 1.39 & 0.08 & 0.57 & 0.57 & 0.56 & 0.50 \\
\hline Aug-1997 & 3.39 & 0.55 & 0.85 & 0.85 & 0.79 & 0.82 \\
\hline Sep-1997 & 1.32 & 0.42 & 0.73 & 0.73 & 0.62 & 0.66 \\
\hline Oct-1997 & 2.60 & 0.80 & 0.87 & 0.87 & 0.84 & 0.84 \\
\hline Nov-1997 & 1.27 & 0.66 & 0.75 & 0.75 & 0.67 & 0.68 \\
\hline Dec-1997 & 4.34 & 0.90 & 0.90 & 0.90 & 0.84 & 0.87 \\
\hline Jan-1998 & 5.88 & 0.89 & 0.87 & 0.87 & 0.85 & 0.85 \\
\hline Mar-2001 & 1.71 & 0.11 & 0.24 & 0.23 & 0.98 & 0.42 \\
\hline Apr-2001 & 2.23 & 0.17 & 0.33 & 0.35 & 0.83 & 0.49 \\
\hline Sep-2001 & -0.57 & 0.61 & 0.68 & 0.88 & 0.87 & 0.73 \\
\hline Oct-2001 & 3.37 & 0.90 & 0.90 & 0.95 & 0.84 & 0.87 \\
\hline
\end{tabular}

Table 4: Singapore - Transition Probabilities 


\begin{tabular}{lccc}
\hline The Philippines & Model $(1,1)$ & $\begin{array}{c}\text { Model }(2,1) \\
\text { REER }\end{array}$ & $\begin{array}{c}\text { Model }(3,1) \\
\text { REER } \\
\text { GENRET }\end{array}$ \\
\hline$\mu_{0}$ & 0.089 & 0.088 & 0.077 \\
$\mu_{1}$ & $(0.038)$ & $(0.038)$ & $(0.041)$ \\
$\omega$ & 0.634 & 0.637 & 0.508 \\
& $(0.304)$ & $(0.300)$ & $(0.254)$ \\
$g$ & 0.119 & 0.119 & 0.098 \\
& $(0.026)$ & $(0.026)$ & $(0.026)$ \\
$\alpha$ & 46.545 & 45.962 & 41.347 \\
& $(12.717)$ & $(12.529)$ & $(12.713)$ \\
& 0.429 & 0.421 & 0.517 \\
$p-$ const & $(0.168)$ & $(0.167)$ & $(0.176)$ \\
& 1.453 & 1.511 & 1.558 \\
$p-G E N R E T$ & $(0.205)$ & $(0.238)$ & $(0.328)$ \\
$q-$ const & & -0.020 & -0.027 \\
$\theta$ & & $(0.034)$ & $(0.051)$ \\
& 1.240 & & 0.002 \\
& $(0.253)$ & $(0.271$ & $1.038)$ \\
AIC & 0.404 & 0.402 & $(0.389)$ \\
SIC & $(0.058)$ & $(0.0597)$ & 0.458 \\
\hline Standard error in parenthesis & & \\
\hline
\end{tabular}

Table 5: The Philippines - Estimation Results 


\begin{tabular}{|c|c|c|c|c|}
\hline The Philippines & ERDEV & $\operatorname{Model}(1,1)$ & $\begin{array}{c}\text { Model }(2,1) \\
\text { REER }\end{array}$ & $\begin{array}{c}\text { Model }(3,1) \\
\text { REER } \\
\text { GENRET }\end{array}$ \\
\hline & & \multicolumn{3}{|c|}{ Transition Probabilities $\left(P_{t \mid t-1}\right)$} \\
\hline $\begin{array}{c}\text { ordinary } \\
\text { period } \\
\text { average }\end{array}$ & 0.06 & 0.08 & 0.07 & 0.08 \\
\hline Oct-1990 & 1.57 & 0.61 & 0.61 & 0.76 \\
\hline Nov-1990 & 8.38 & 0.89 & 0.90 & 0.95 \\
\hline Jun-1997 & 0.04 & 0.08 & 0.11 & 0.12 \\
\hline Jul-1997 & 4.77 & 0.89 & 0.90 & 0.95 \\
\hline Aug-1997 & 5.83 & 0.82 & 0.83 & 0.92 \\
\hline Sep-1997 & 9.92 & 0.86 & 0.87 & 0.93 \\
\hline Oct-1997 & 6.19 & 0.78 & 0.79 & 0.89 \\
\hline Nov-1997 & 0.17 & 0.74 & 0.74 & 0.92 \\
\hline Dec-1997 & 7.40 & 0.89 & 0.90 & 0.95 \\
\hline Jan-1998 & 13.78 & 0.83 & 0.84 & 0.92 \\
\hline Jun-2000 & 1.99 & 0.66 & 0.66 & 0.85 \\
\hline Jul-2000 & 3.89 & 0.88 & 0.89 & 0.95 \\
\hline Aug-2000 & 1.26 & 0.76 & 0.77 & 0.89 \\
\hline Sep-2000 & 1.85 & 0.87 & 0.88 & 0.92 \\
\hline Oct-2000 & 5.05 & 0.89 & 0.90 & 0.95 \\
\hline Mar-2001 & 0.37 & 0.80 & 0.81 & 0.91 \\
\hline Apr-2001 & 3.49 & 0.82 & 0.83 & 0.90 \\
\hline May-2001 & 0.69 & 0.70 & 0.71 & 0.84 \\
\hline Jun-2001 & 1.86 & 0.81 & 0.82 & 0.87 \\
\hline Jul-2001 & 3.30 & 0.86 & 0.87 & 0.92 \\
\hline
\end{tabular}

Table 6: The Philippines - Transition Probabilities 


\begin{tabular}{|c|c|c|c|c|}
\hline Malaysia & Model $(1,1)$ & $\begin{array}{l}\text { Model }(2,1) \\
\text { REER }\end{array}$ & $\begin{array}{c}\text { Model }(3,1) \\
\text { REER } \\
\text { M2ratio }\end{array}$ & $\begin{array}{c}\text { Model }(3,1) \\
\text { REER } \\
\text { BANKVOL }\end{array}$ \\
\hline$\mu_{0}$ & $\begin{array}{c}-0.020 \\
(0.074)\end{array}$ & $\begin{array}{l}0.015 \\
(0.072)\end{array}$ & $\begin{array}{c}-0.040 \\
(0.076)\end{array}$ & $\begin{array}{c}-0.025 \\
(0.076)\end{array}$ \\
\hline$\mu_{1}$ & $\begin{array}{l}1.101 \\
(0.992)\end{array}$ & $\begin{array}{l}1.370 \\
(1.071)\end{array}$ & $\begin{array}{l}1.232 \\
(0.962)\end{array}$ & $\begin{array}{l}2.133 \\
(1.542)\end{array}$ \\
\hline$\omega$ & $\begin{array}{l}0.424 \\
(0.160)\end{array}$ & $\begin{array}{l}0.531 \\
(0.147)\end{array}$ & $\begin{array}{l}0.528 \\
(0.147)\end{array}$ & $\begin{array}{l}0.445 \\
(0.116)\end{array}$ \\
\hline$g$ & $\begin{array}{l}37.66 \\
(15.48)\end{array}$ & $\begin{array}{l}37.716 \\
(16.390)\end{array}$ & $\begin{array}{l}34.084 \\
(14.618)\end{array}$ & $\begin{array}{l}65.055 \\
(23.434)\end{array}$ \\
\hline$\alpha$ & $\begin{array}{l}0.238 \\
(0.137)\end{array}$ & $\begin{array}{l}0.201 \\
(0.140)\end{array}$ & $\begin{array}{l}0.195 \\
(0.122)\end{array}$ & $\begin{array}{l}0.000 \\
(0.000)\end{array}$ \\
\hline$\beta$ & $\begin{array}{l}0.155 \\
(0.142)\end{array}$ & $\begin{array}{l}0.157 \\
(0.175)\end{array}$ & $\begin{array}{l}0.129 \\
(0.166)\end{array}$ & $\begin{array}{l}0.376 \\
(0.129)\end{array}$ \\
\hline$p-$ const & $\begin{array}{l}1.885 \\
(0.326)\end{array}$ & $\begin{array}{l}2.498 \\
(0.519)\end{array}$ & $\begin{array}{l}3.442 \\
(1.086)\end{array}$ & $\begin{array}{l}4.166 \\
(1.571)\end{array}$ \\
\hline$p-R E E R$ & & $\begin{array}{c}-0.101 \\
(0.057)\end{array}$ & $\begin{array}{c}-0.124 \\
(0.095)\end{array}$ & $\begin{array}{c}-0.189 \\
(0.099)\end{array}$ \\
\hline$p-M 2$ ratio & & & $\begin{array}{l}-21.184 \\
(10.326)\end{array}$ & \\
\hline$p-B A N K V O L$ & & & & $\begin{array}{c}-0.117 \\
(0.077)\end{array}$ \\
\hline$q-$ const & $\begin{array}{l}0.925 \\
(0.448)\end{array}$ & $\begin{array}{l}1.209 \\
(0.388)\end{array}$ & $\begin{array}{l}1.101 \\
(0.345)\end{array}$ & $\begin{array}{l}1.462 \\
(1.180)\end{array}$ \\
\hline$\theta$ & $\begin{array}{l}0.261 \\
(0.088)\end{array}$ & $\begin{array}{l}0.259 \\
(0.087)\end{array}$ & $\begin{array}{l}0.271 \\
(0.085)\end{array}$ & $\begin{array}{l}0.269 \\
(0.269)\end{array}$ \\
\hline $\mathrm{AIC}$ & 3.3701 & 3.3653 & 3.3724 & 3.2960 \\
\hline $\mathrm{SIC}$ & 3.5381 & 3.5520 & 3.5778 & 3.5148 \\
\hline
\end{tabular}

Table 7: Malaysia - Estimation Results 


\begin{tabular}{|c|c|c|c|c|c|}
\hline Malaysia & ERDEV & Model $(1,1)$ & $\begin{array}{c}\text { Model }(2,1) \\
\text { REER }\end{array}$ & $\begin{array}{c}\text { Model }(3,1) \\
\text { REER } \\
\text { M2ratio }\end{array}$ & $\begin{array}{c}\text { Model }(3,1) \\
\text { REER } \\
\text { BANKVOL }\end{array}$ \\
\hline \multirow[b]{2}{*}{$\begin{array}{c}\text { ordinary } \\
\text { period } \\
\text { average }\end{array}$} & \multirow[b]{2}{*}{0.05} & \multicolumn{4}{|c|}{ Transition Probabilities $\left(P_{t \mid t-1}\right)$} \\
\hline & & 0.05 & 0.01 & 0.01 & 0.005 \\
\hline Dec-1993 & 0.78 & 0.04 & 0.02 & 0.01 & 0.33 \\
\hline Jan-1994 & 5.30 & 0.82 & 0.88 & 0.86 & 0.93 \\
\hline Jun-1997 & 0.40 & 0.04 & 0.20 & 0.18 & 0.25 \\
\hline Jul-1997 & 1.96 & 0.15 & 0.45 & 0.94 & 0.49 \\
\hline Aug-1997 & 6.41 & 0.82 & 0.88 & 0.86 & 0.92 \\
\hline Sep-1997 & 9.40 & 0.78 & 0.86 & 0.84 & 0.91 \\
\hline Oct-1997 & 8.89 & 0.70 & 0.81 & 0.78 & 0.89 \\
\hline Nov-1997 & 2.99 & 0.53 & 0.66 & 0.61 & 0.74 \\
\hline Dec-1997 & 10.62 & 0.82 & 0.89 & 0.86 & 0.91 \\
\hline Jan-1998 & 15.68 & 0.77 & 0.86 & 0.84 & 0.92 \\
\hline Apr-1998 & -0.53 & 0.37 & 0.50 & 0.45 & 0.63 \\
\hline May-1998 & 2.38 & 0.34 & 0.44 & 0.46 & 0.49 \\
\hline Jun-1998 & 4.35 & 0.57 & 0.69 & 0.71 & 0.67 \\
\hline
\end{tabular}

Table 8: Malaysia - Transition Probailities 
Fig. 1: Thai baht Volatility

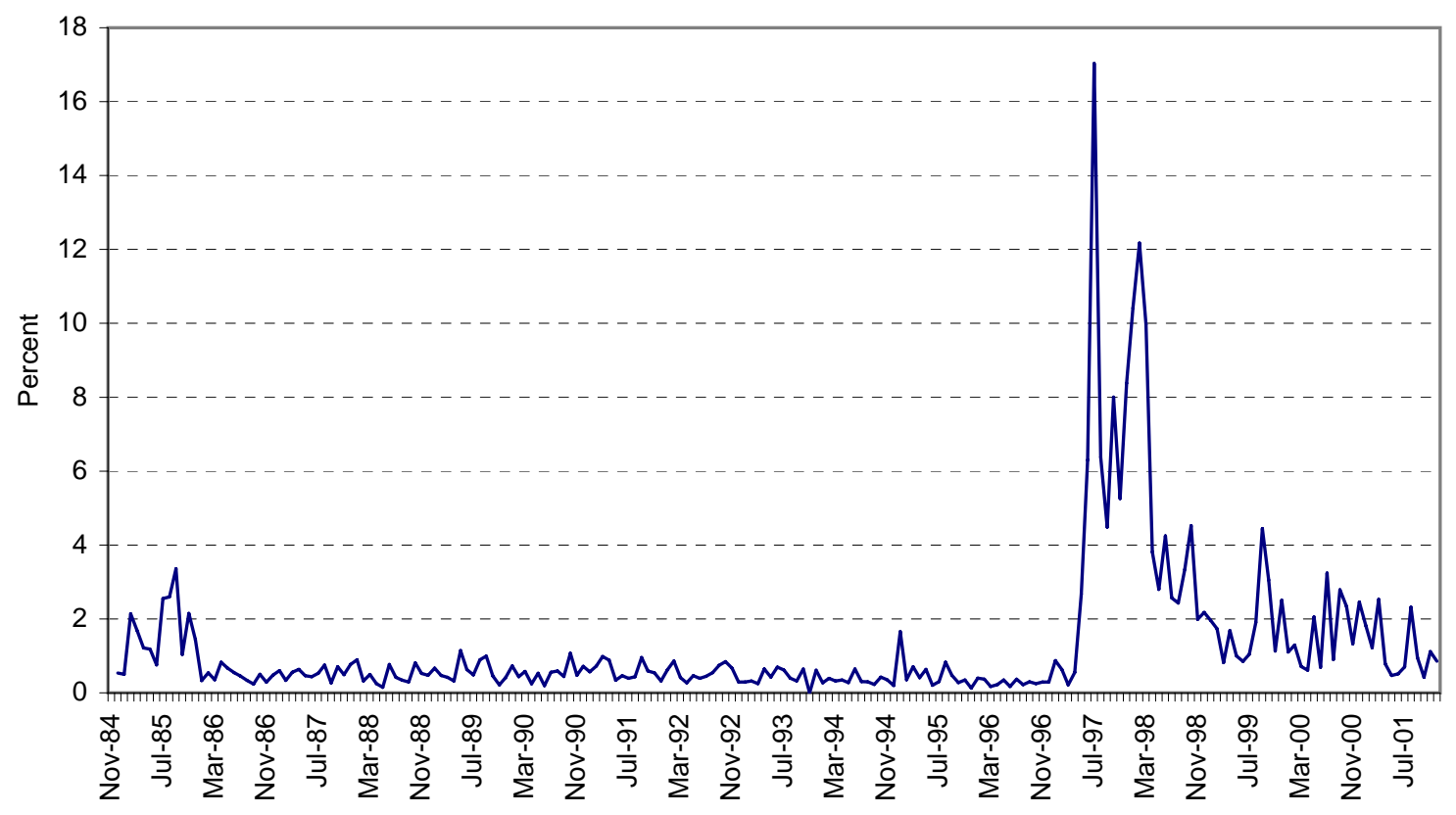

Fig. 2: Thai baht - Returns and Standard Deviations

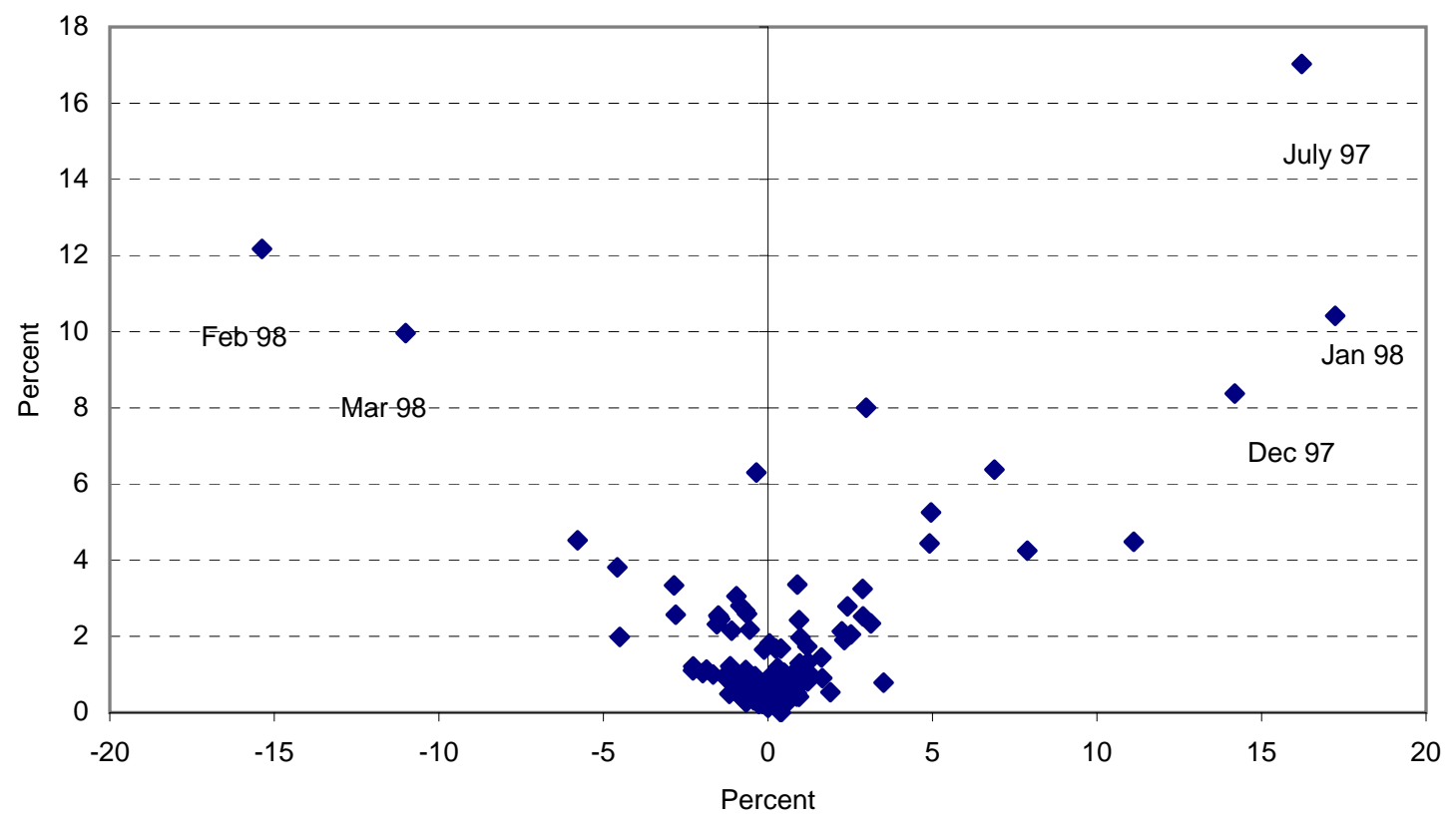


Fig. 3 : Thailand

Panel A - External Sector

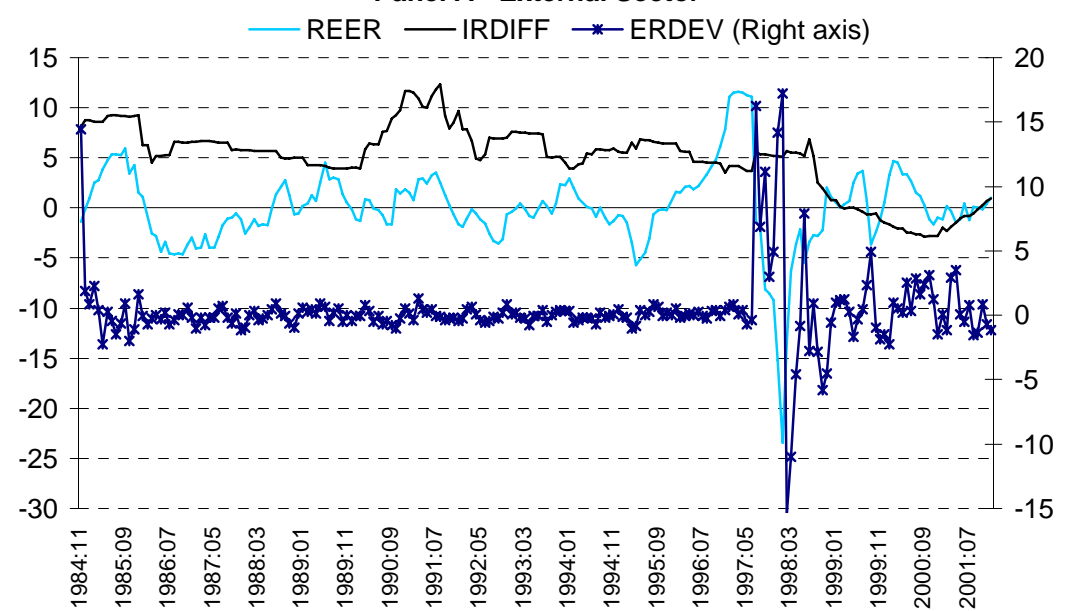

$\stackrel{\omega}{\mapsto}$

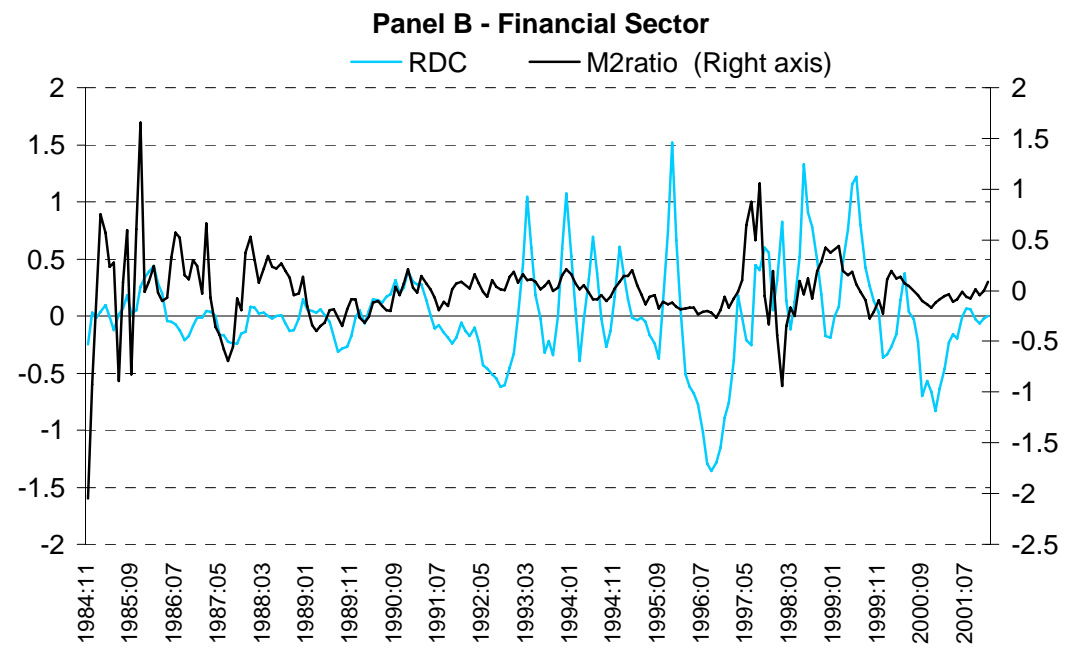

Panel C - Real Sector

- GENRET — GENVOL (Right axis)

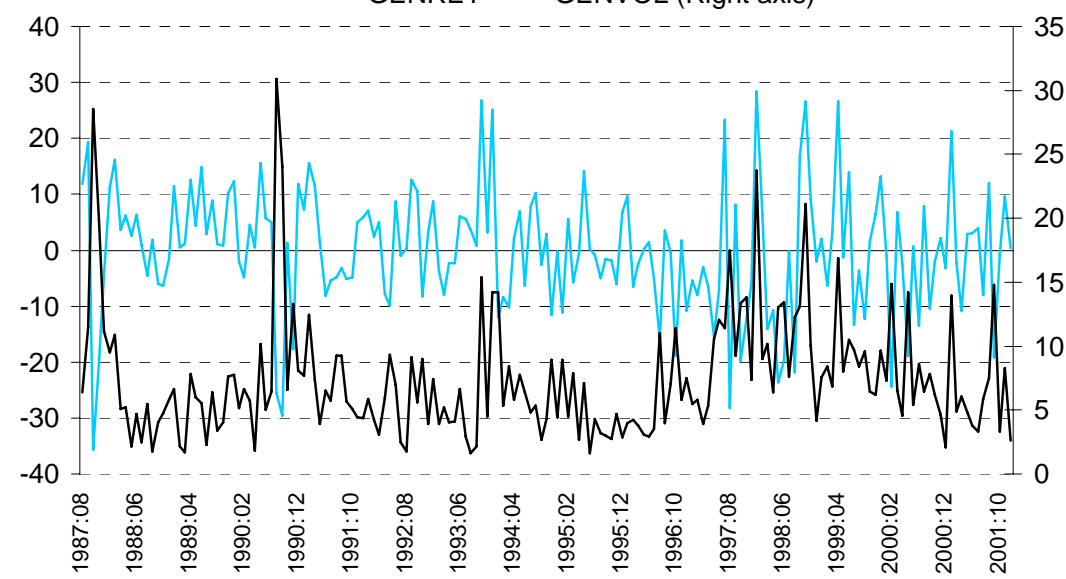

Panel D - Banking Sector

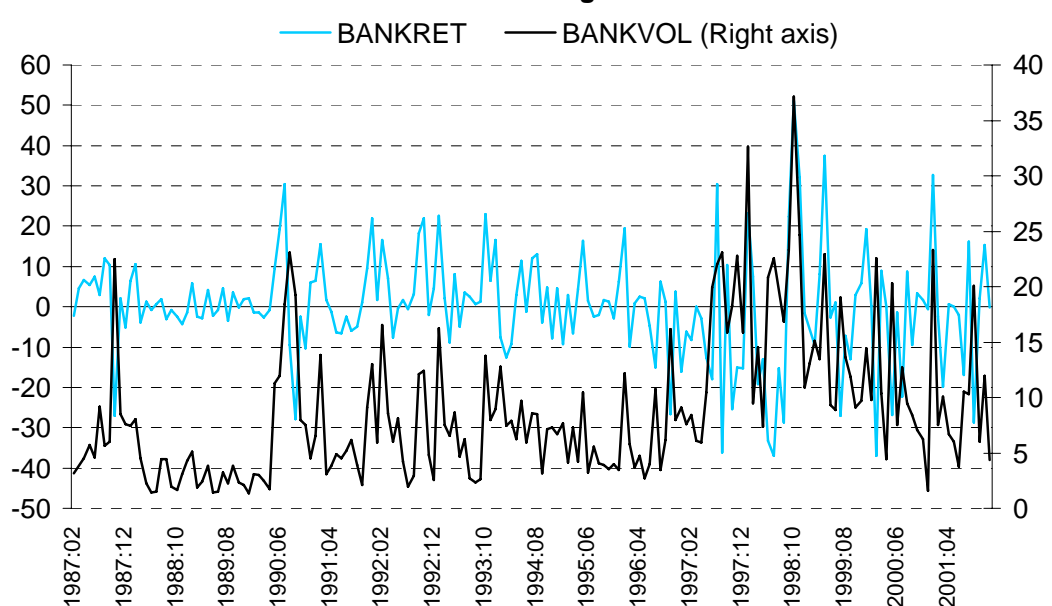

These panels show the evolution of a number of Thai indicators over the period November 1984 to July 2001 (stock market and banking sector data start in January 1987). REER is the

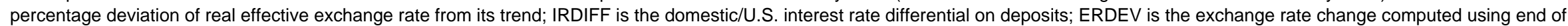
the month log-first difference; RDC is the deviation of the ratio between real domestic credit and GDP from its trend; M2ratio is the deviation of the ratio of M2 over reserves from its trend;

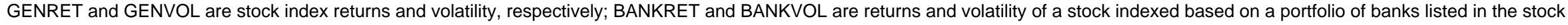
market. 
Panel A - External Sector

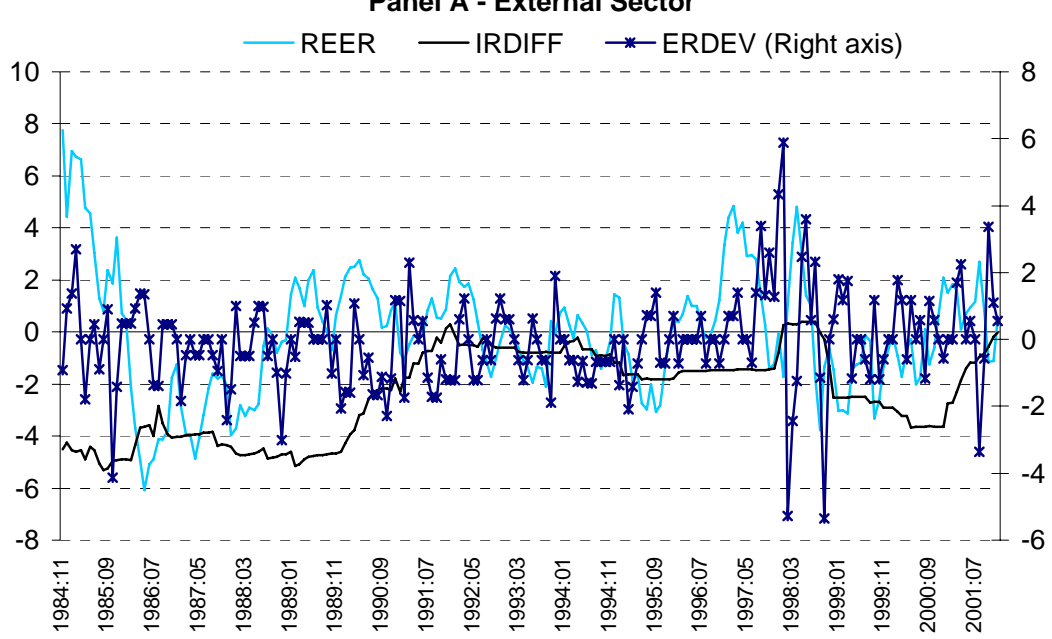

$\stackrel{\omega}{N}$

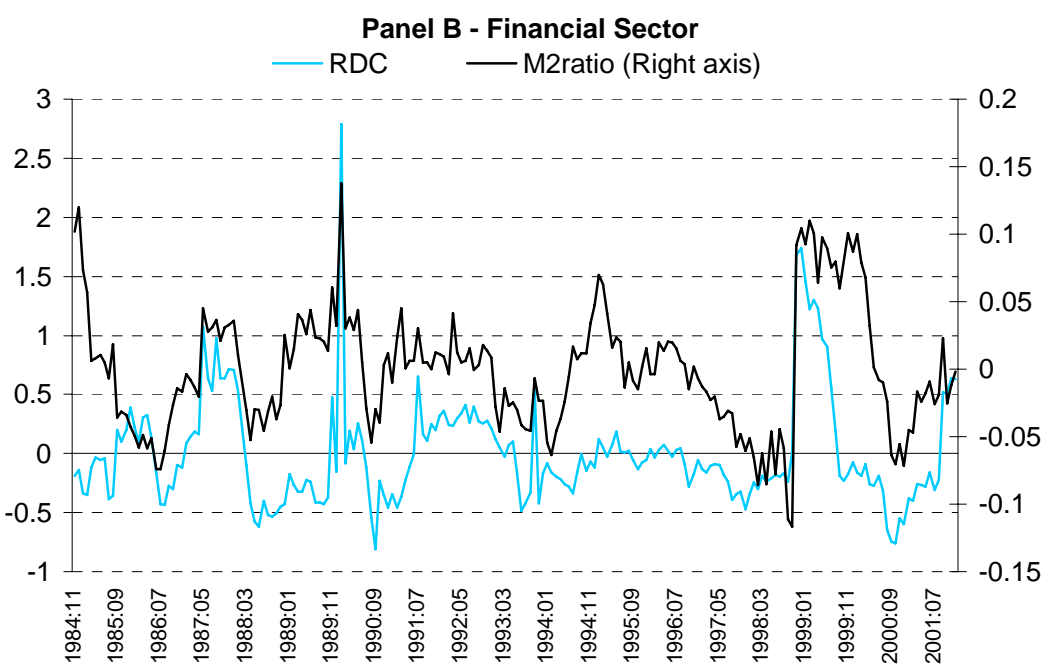

Panel C- Real Sector

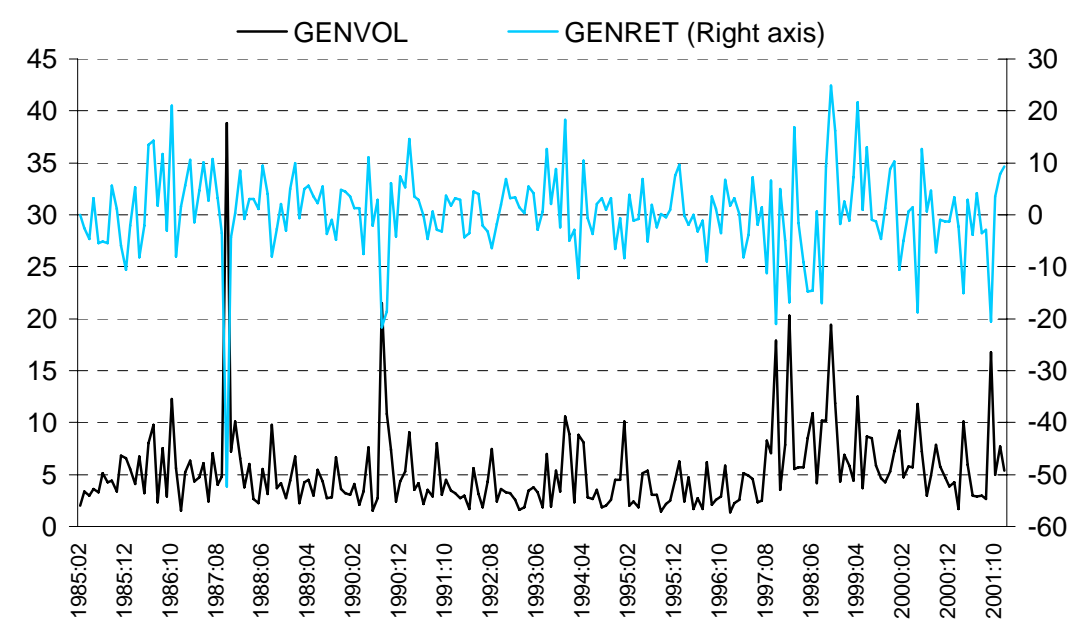

Panel D - Banking Sector

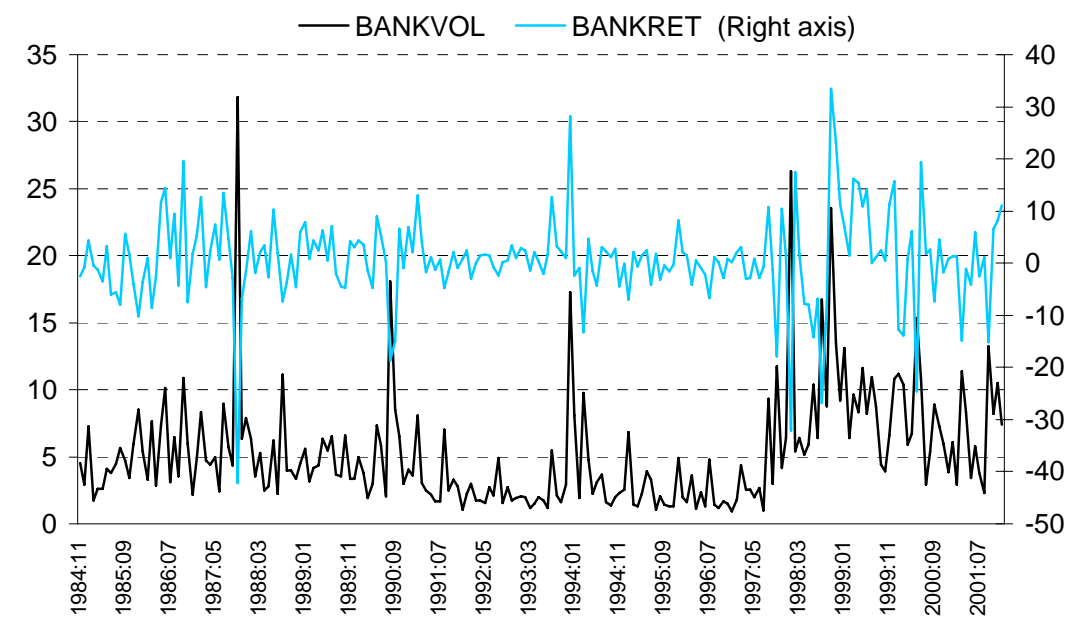

These panels show the evolution of a number of Singaporean indicators over the period November 1984 to July 2001 (stock market data start in January 1985). REER is the percentage

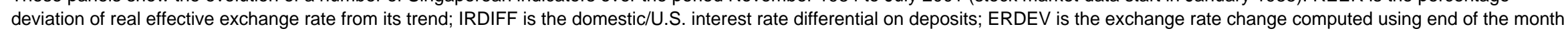
log-first difference; RDC is the deviation of the ratio between real domestic credit and GDP from its trend; M2ratio is the deviation of the ratio of M2 over reserves from its trend; GENRET and GENVOL are stock index returns and volatility, respectively; BANKRET and BANKVOL are returns and volatility of a stock indexed based on a portfolio of banks listed in the stock market. 
Fig. 5: Philippines

Panel A - External Sector
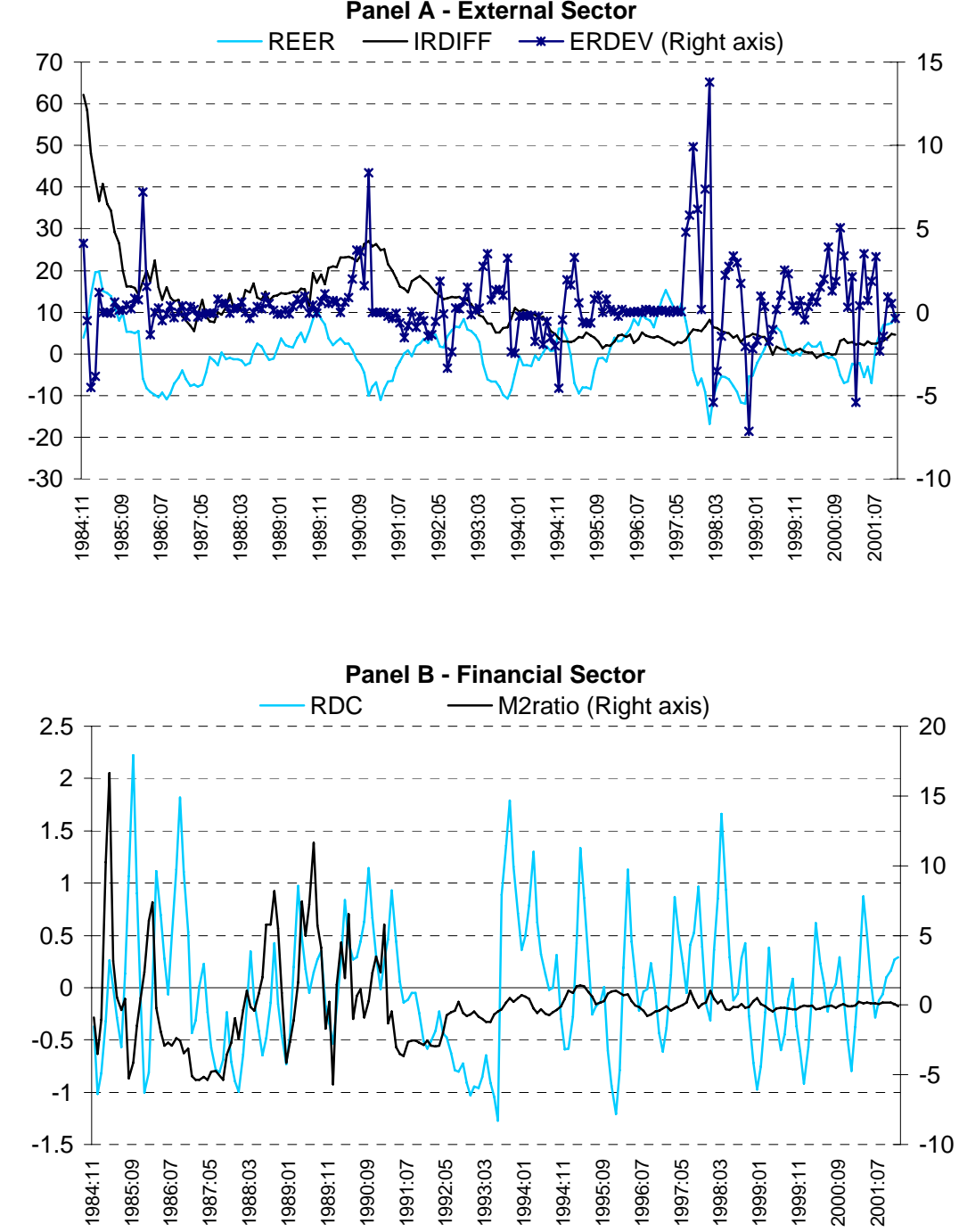

Panel C - Real Sector

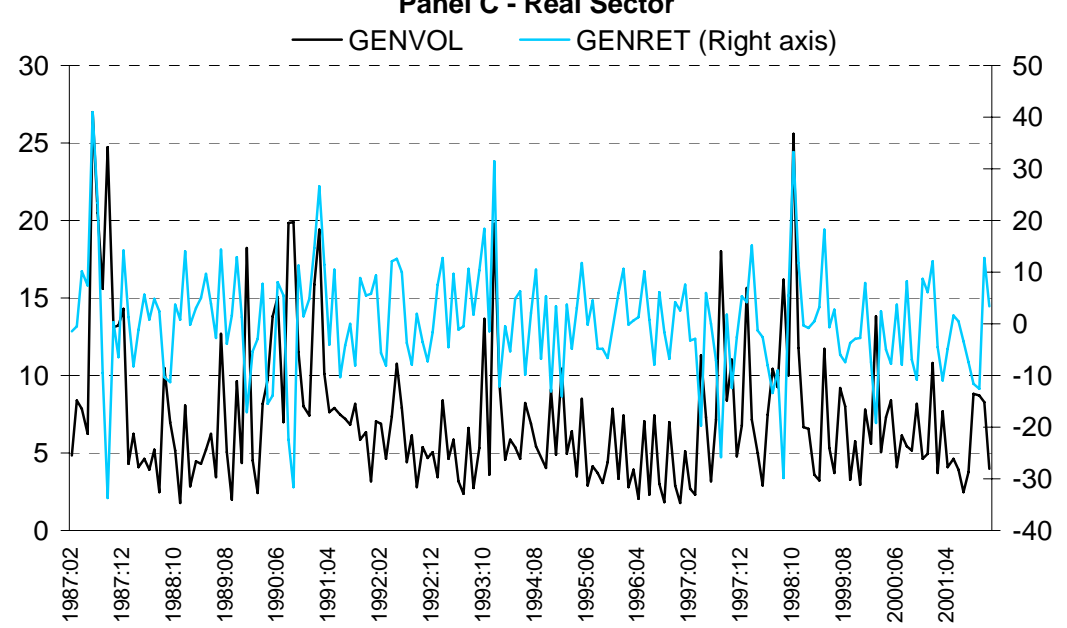

These panels show the evolution of a number of Philippine indicators over the period November 1984 to July 2001 (stock market and banking sector data start in January 1987 and January respectively). REER is the percentage deviation of real effective exchange rate from its trend; IRDIFF is the domestic/U.S. interest rate differential on deposits; ERDEV is the exchange rate change computed using end of the month log-first difference; RDC is the deviation of the ratio between real domestic credit and GDP from its trend; M2ratio is the deviation of the ratio of M2 reserves from its trend; GENRET and GENVOL are stock index returns and volatility, respectively; BANKRET and BANKVOL are returns and volatility of a stock indexed based on a portfolio of banks listed in the stock market.

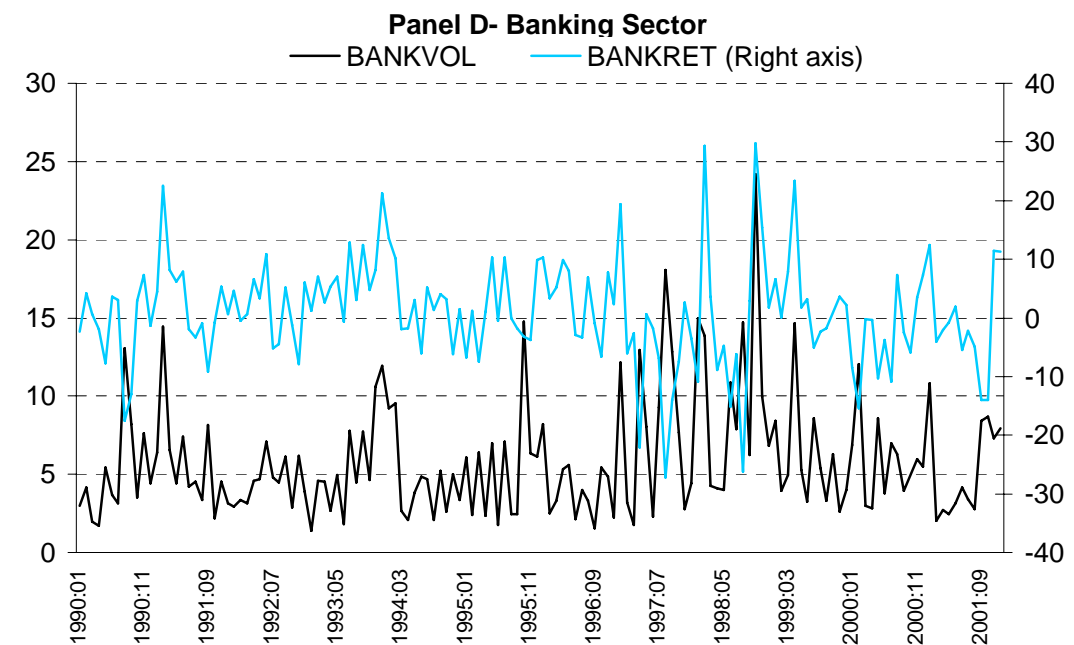


Fig. 6: Malaysia

Panel A - External Sector

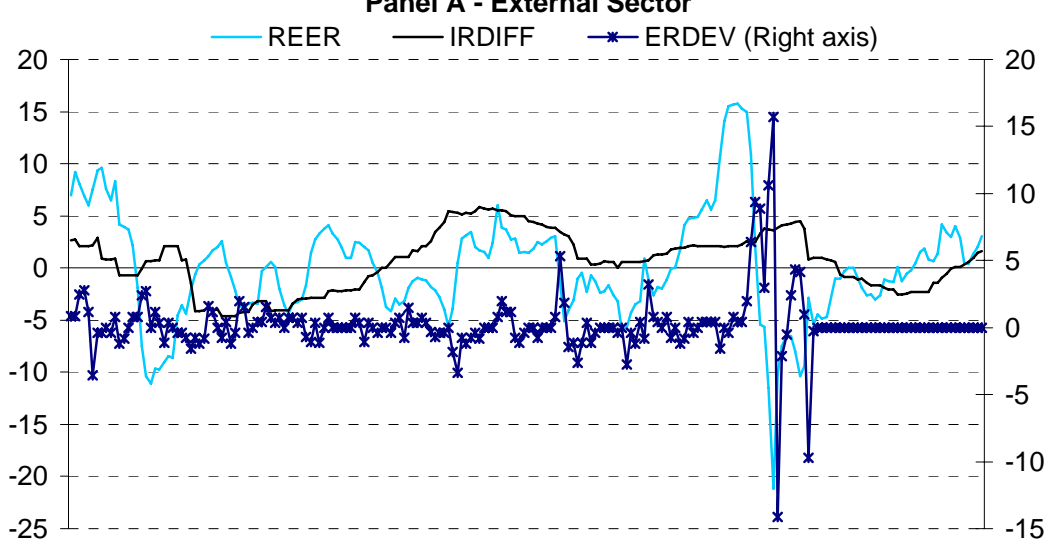

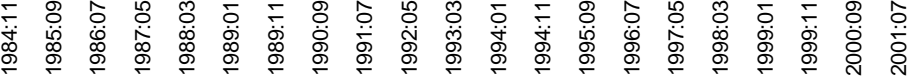

Panel B - Financial Sector

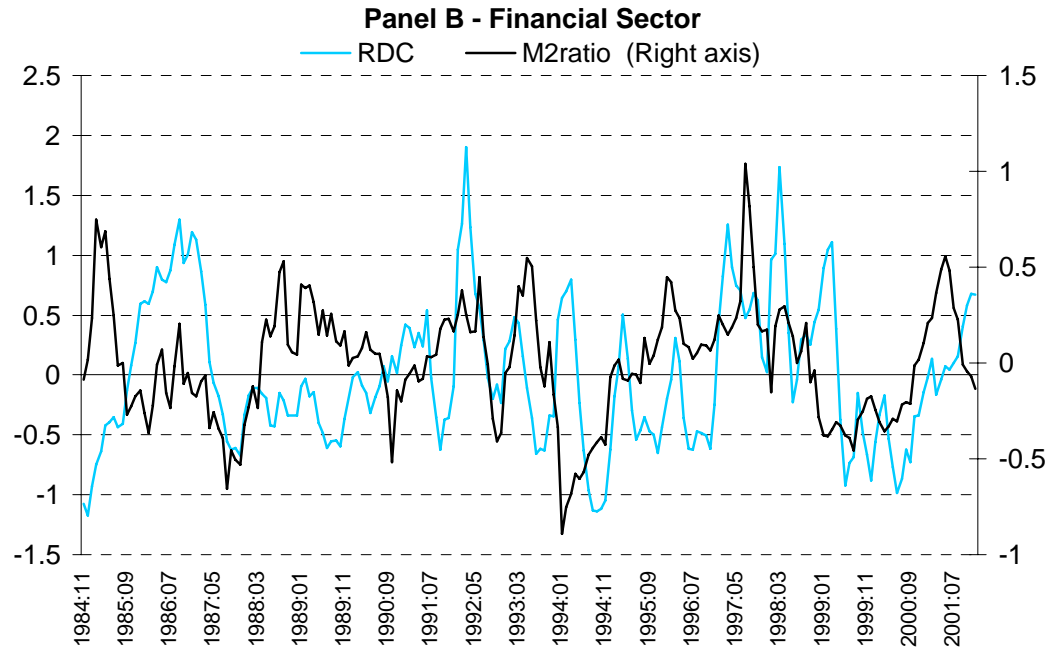

Panel C - Real Sector

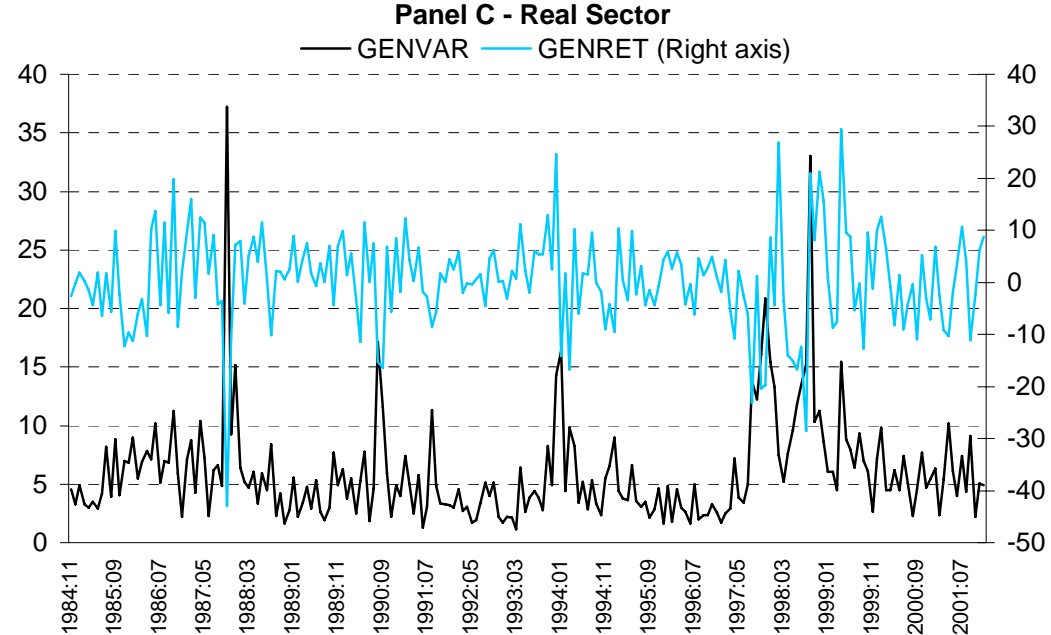

Panel D- Banking Sector

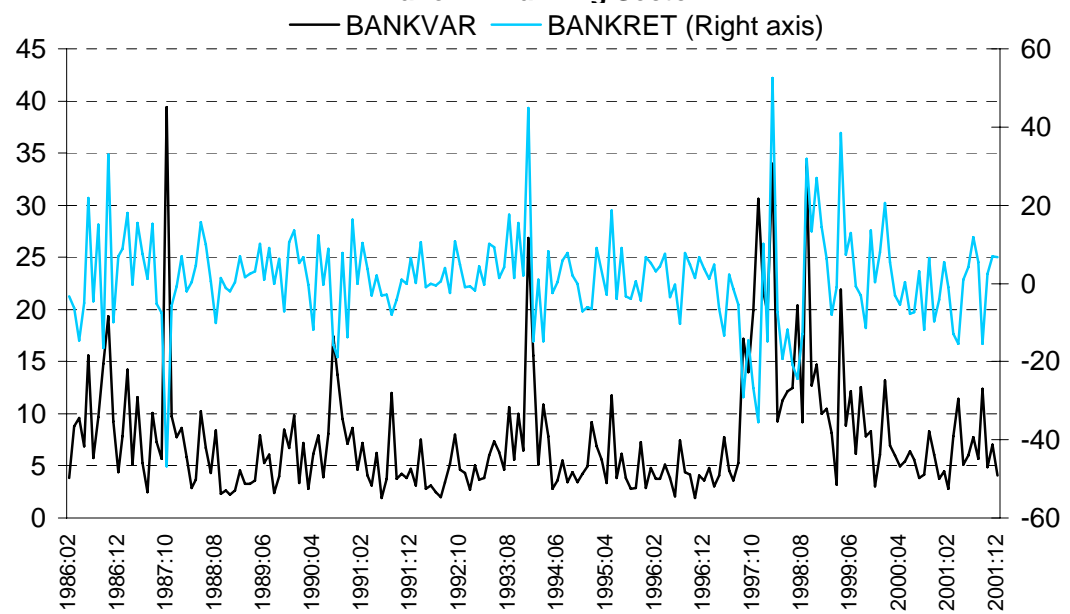

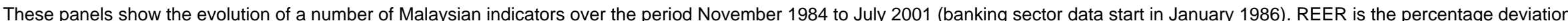
of real effective exchange rate from its trend; IRDIFF is the domestic/U.S. interest rate differential on deposits; ERDEV is the exchange rate change computed using end of the month log-first difference; RDC is the deviation of the ratio between real domestic credit and GDP from its trend; M2ratio is the deviation of the ratio of M2 over reserves from its trend; GENRET and GENVOL are stock index returns and volatility, respectively; BANKRET and BANKVOL are returns and volatility of a stock indexed based on a portfolio of banks listed in the stock market. 
Fig. 7: Thailand

Panel A - Model31 (REER,M2ratio)

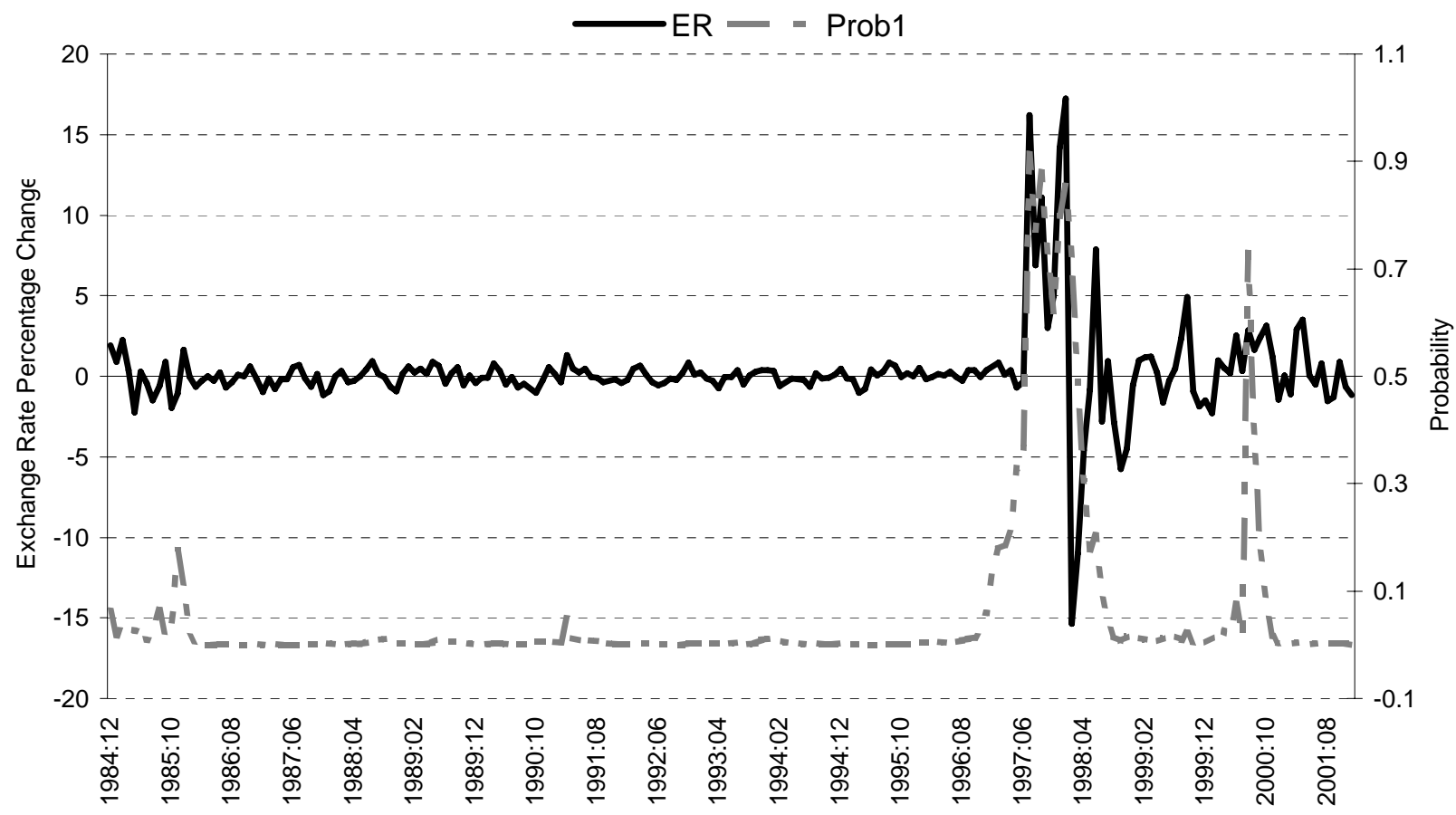

Panel B - Model31 (REER, BANKRET)

$\longrightarrow \mathrm{ER}=-$ Prob1

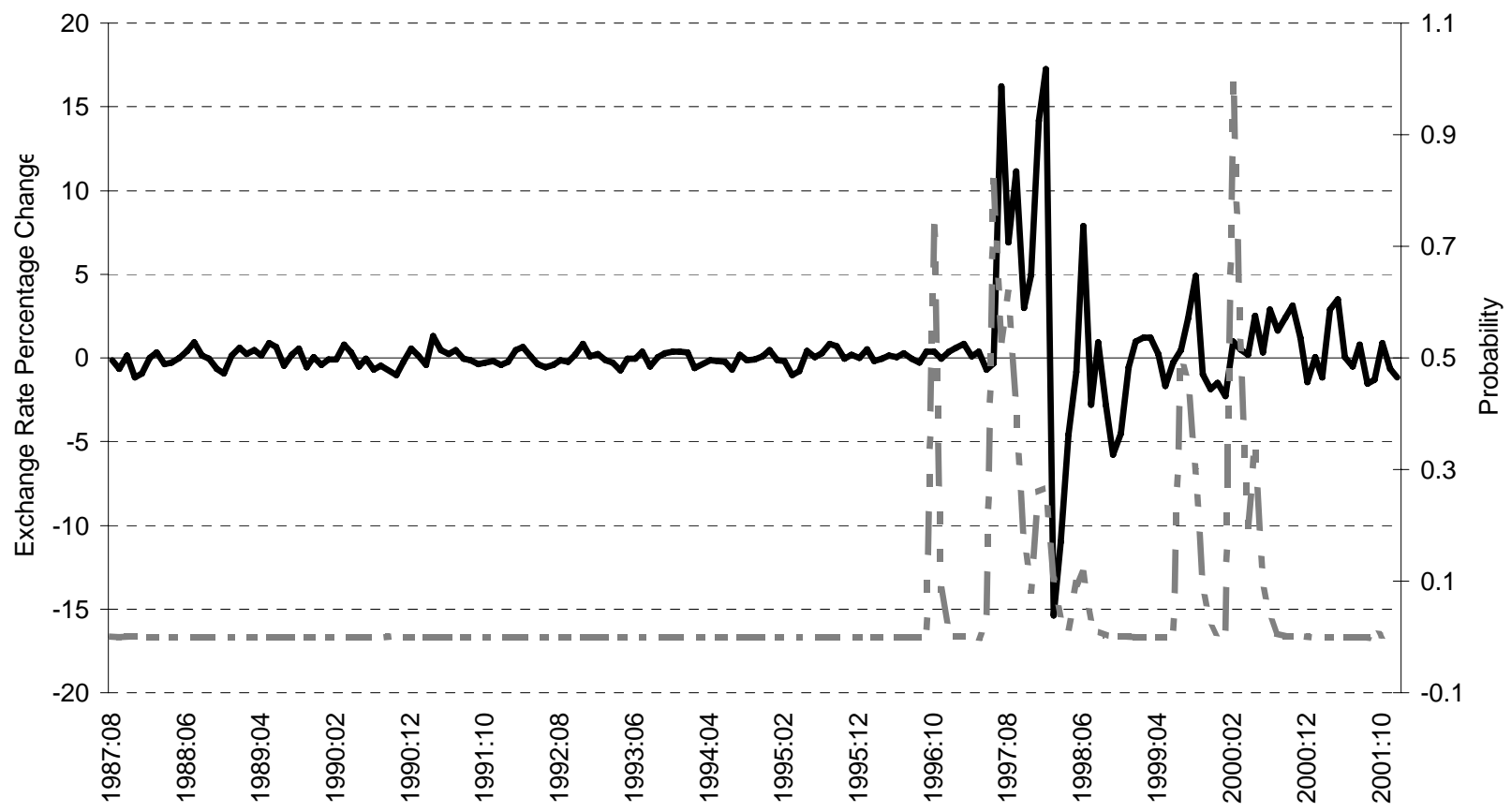


Fig. 8 : Singapore

Panel A - Model22 (REER)

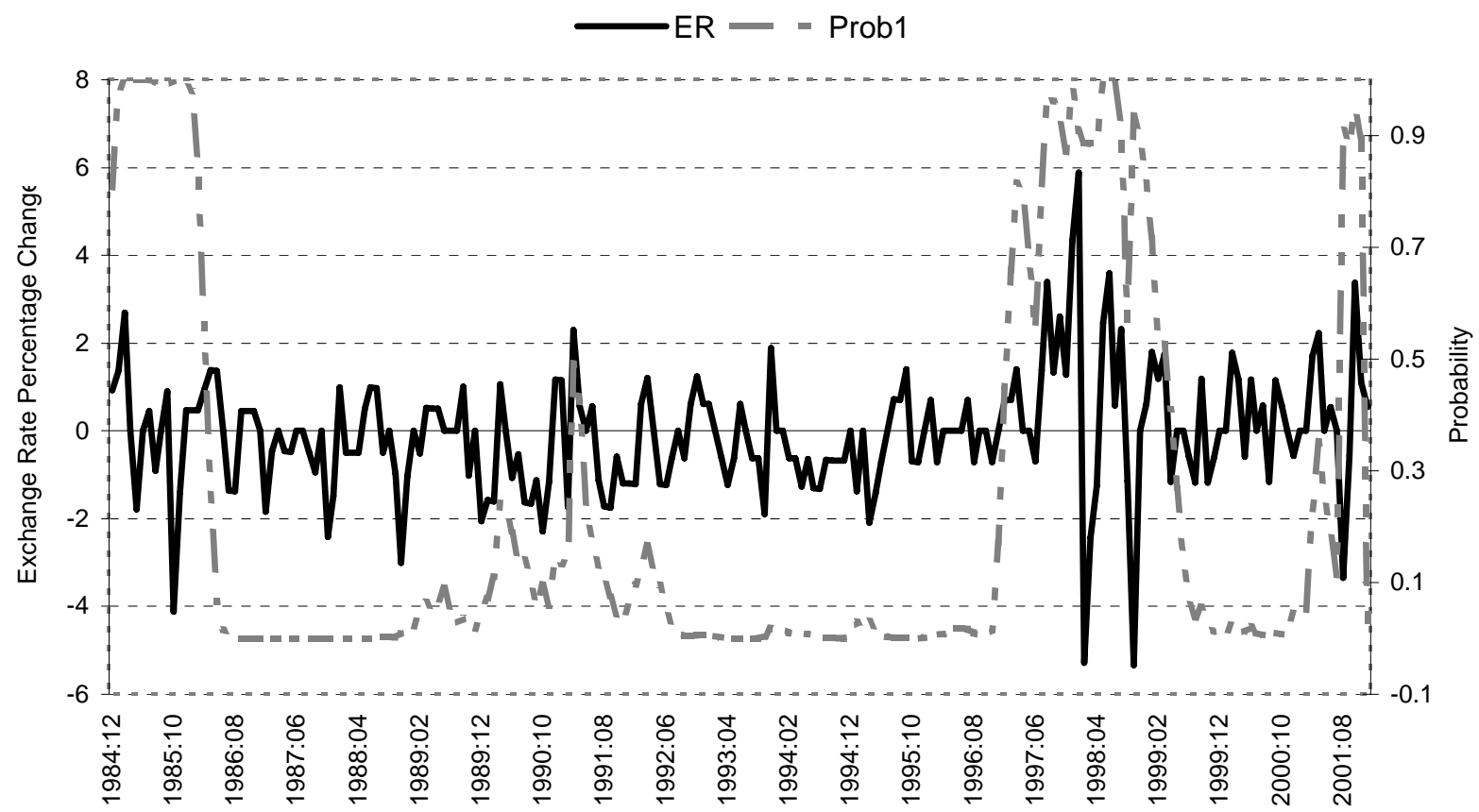

Panel B - Model31 (REER, BANKSTD)

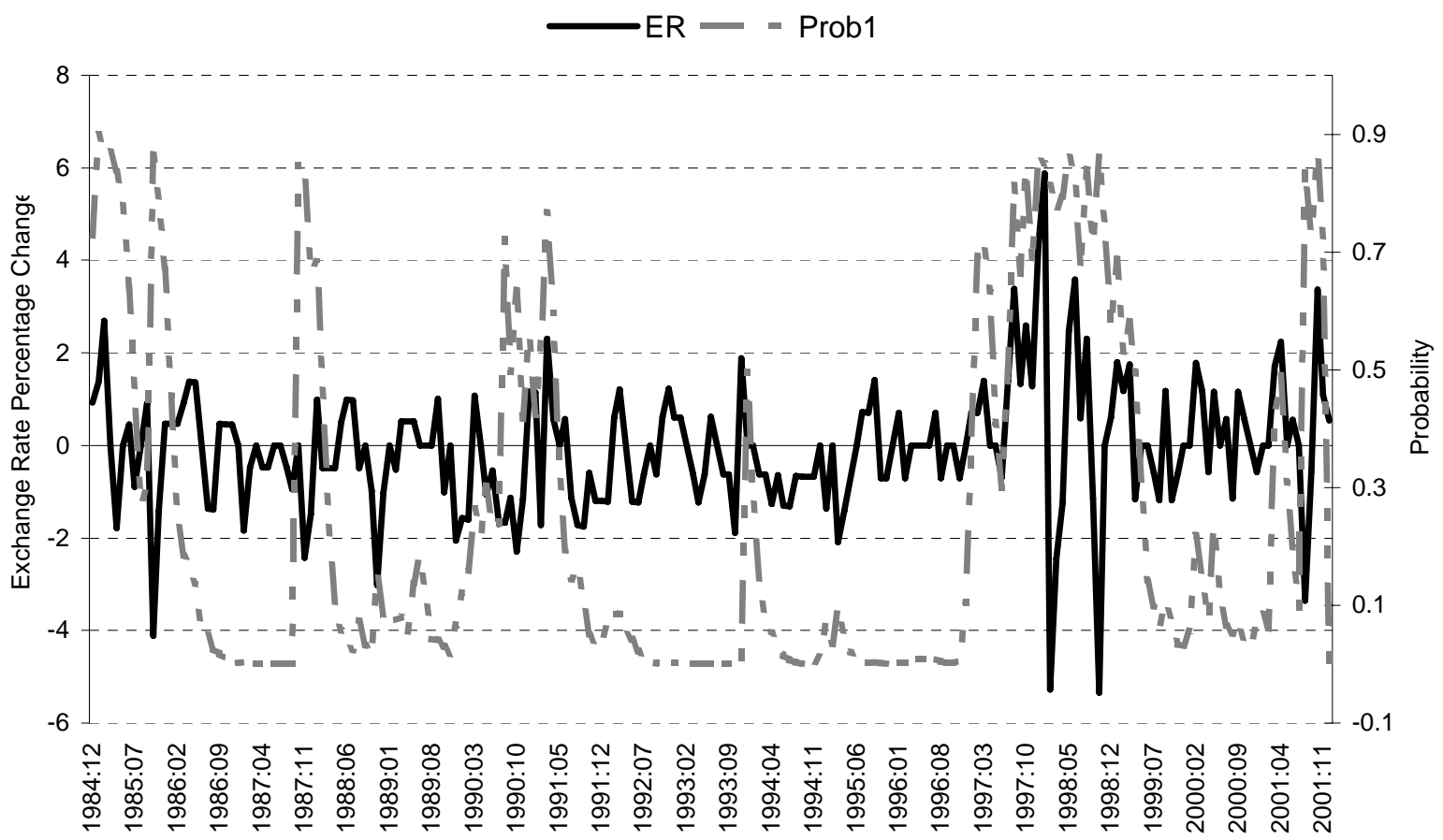


Fig. 9: Philippines

Panel A - Model21 (REER)

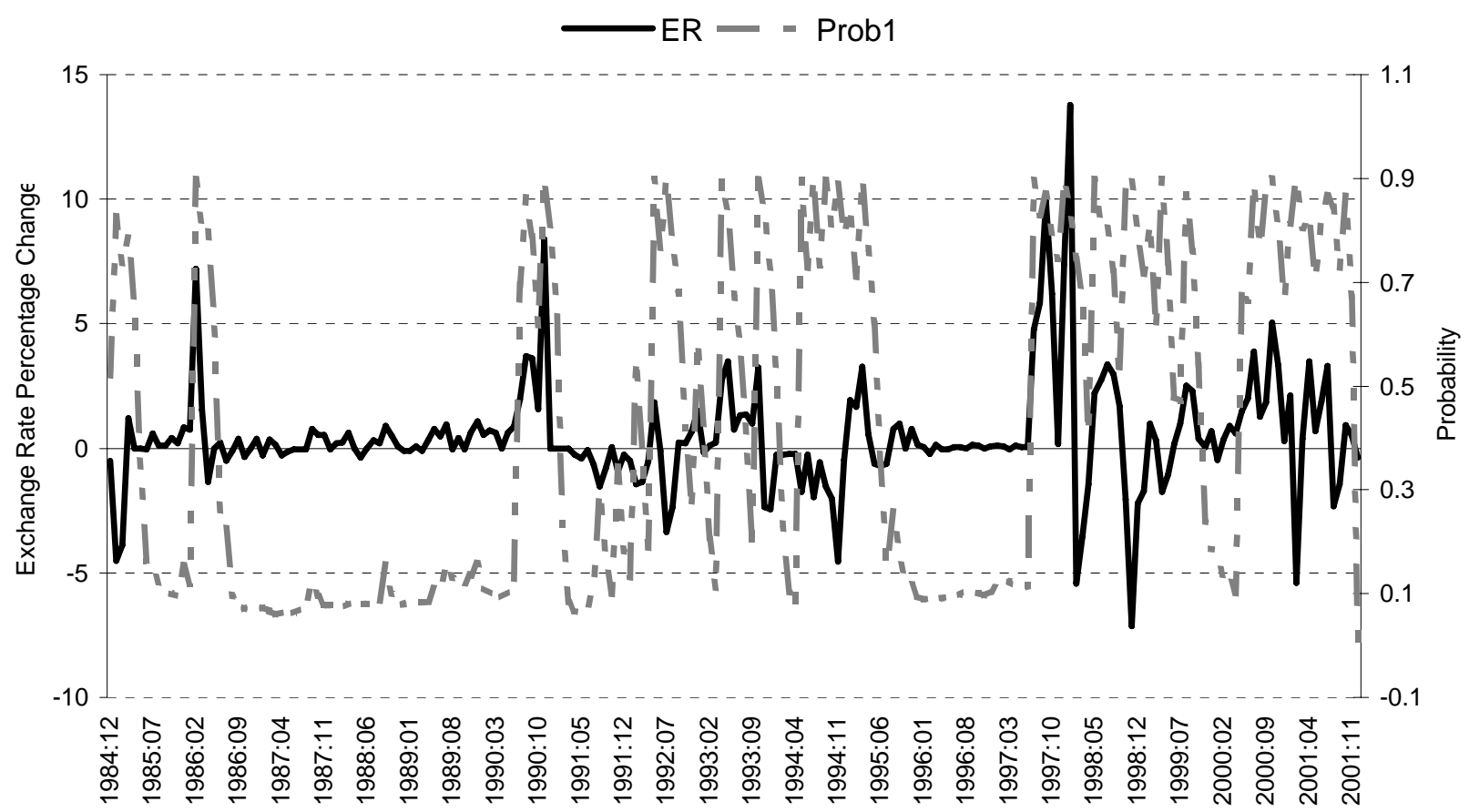

Panel B - Model31 (REER, GENRET)

—ER - = Prob1

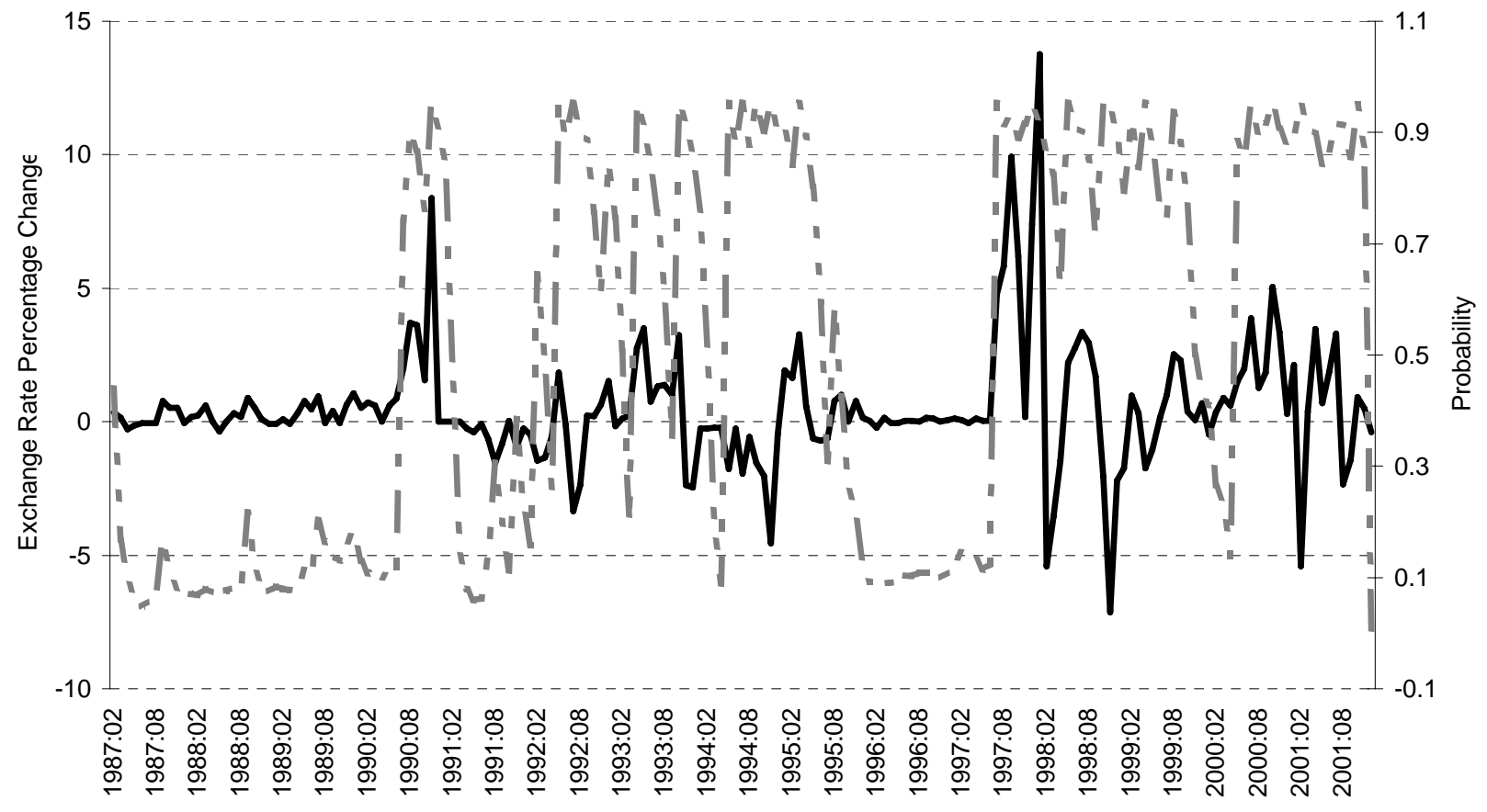


Fig. 10: Malaysia

\section{Panel A - Model31 (REER,M2ratio)}

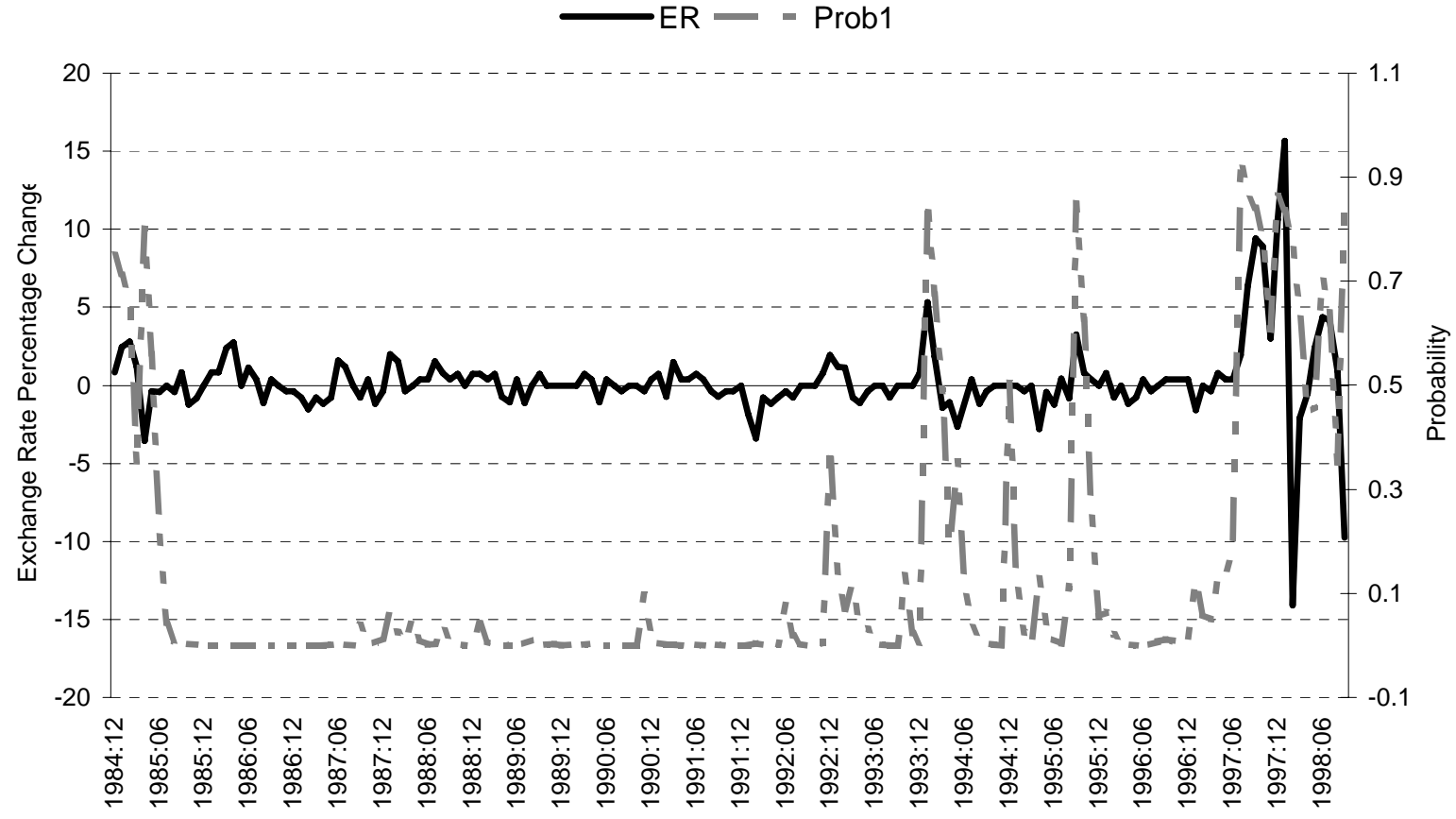

Panel B - Model32 (REER,BANKSTD)

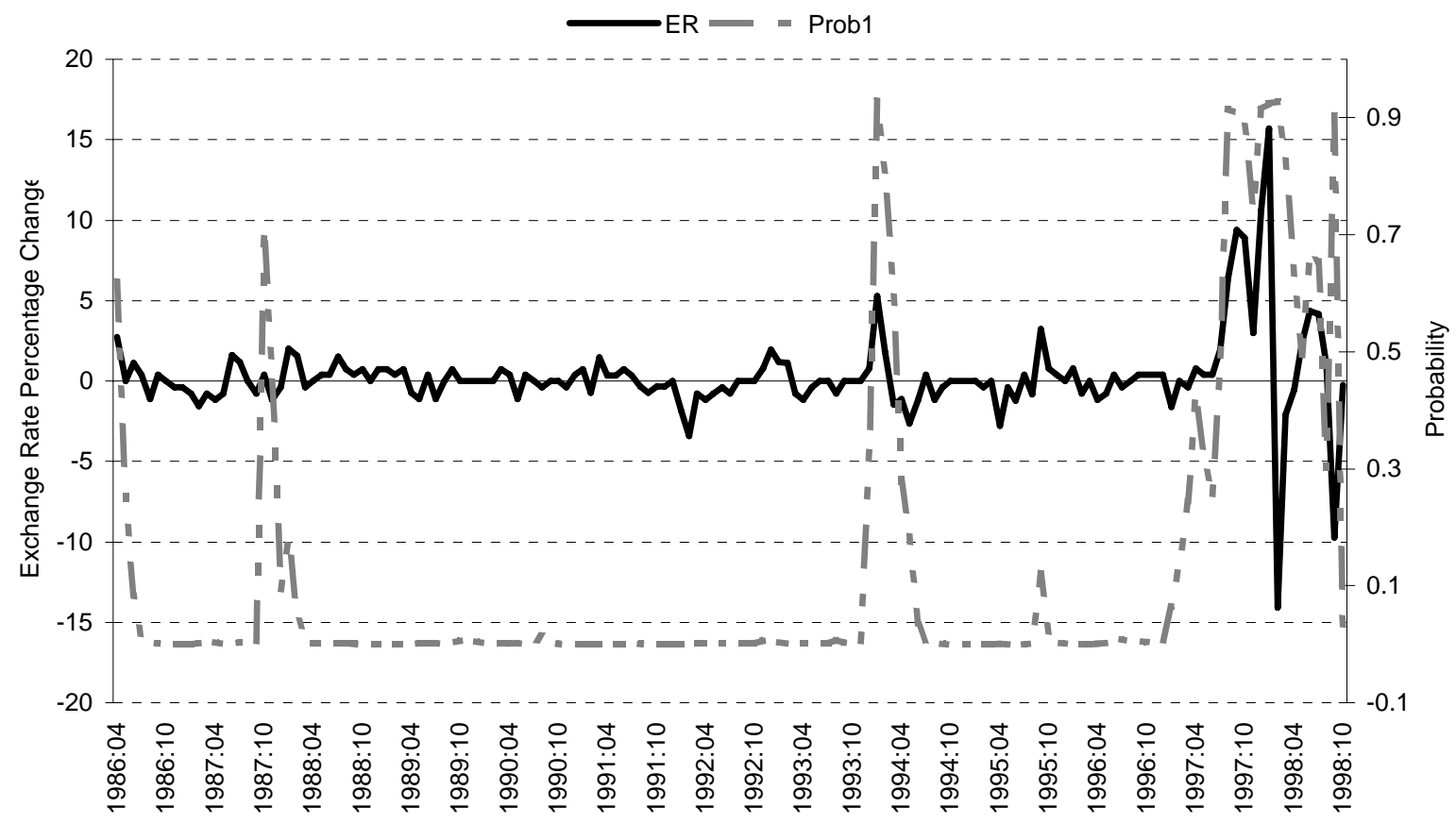

